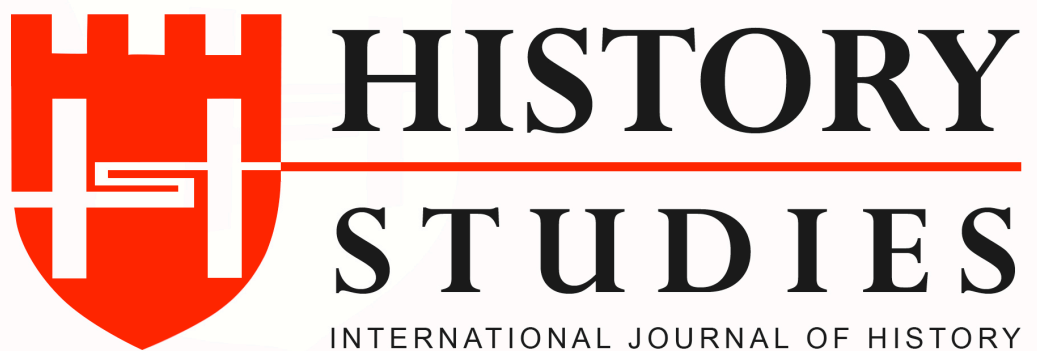

ISSN: 13094173 (Online) 1309 - 4688 (Print)

Volume 11 Issue 5, October 2019

DOI Number: 10.9737/hist.2019.781

Araştırma Makalesi

Makalenin Geliş Tarihi: 22.08.2019 Kabul Tarihi: 24.09.2019

Atıf Künyesi: Mesut Karakulak, “Türkistan'da Diplomasinin Dönüşümü: Pazuhin Kardeşlerin Hive, Buhara ve Hindistan Misyonu 1669-1673", History Studies, 11/5, Ekim 2019, s. 1607-1626.

\title{
Türkistan'da Diplomasinin Dönüşümü: Pazuhin Kardeşlerin Hive, Buhara ve Hindistan Misyonu 1669-1673
}

Transformation of Diplomacy in Turkestan: Mission of Pazuhin Brothers to Bukhara, Hive and India 1669-1673

\author{
Dr. Mesut Karakulak \\ ORCID No: 0000-0002-0142-9170 \\ Ordu Üniversitesi
}

\begin{abstract}
Özet: Rus Çarı Aleksey Mihayloviç (1645-1676) tarafından görevlendirilen Boris ve Semen Pazuhin kardeşlerin 1669-1673 yılları arası Hive ve Buhara Hanlıklarına gerçekleştirdiği seyahat daha önce bölgeye gönderilen elçilik ziyaretlerine nazaran başarılı görülmüş ve onların Türkistan gözlemleri var olan bilginin derinlemeşsini sağlamıştır. Bilhassa diplomatik ritüeller oldukça detaylı tasvir edilmiştir. Aynı zamanda bu elçilik heyeti dolaylı olarak Türkistan hanlıklarının periferisi, Hindistan'a giden ticaret yolları ve Türkistan'daki Rus esirlerinin durumu hakkında tafsilatlı malumata erişime imkân sunmaktadır.
\end{abstract}

Anahtar Kelimeler: Rus Çarlığı, Buhara Hanlığı, Hive Hanlığı, Boris Pazuhin, Rus esirleri

\begin{abstract}
Boris and Semen Pazuhin brothers made an embassy trip to Hive, Bukhara Khanates and Turkistan between 1669-1673. This mission was successful compared to previous embassies and this embassy committee prepared more detailed and comprehensive reports, and these remain to the present day. Especially diplomatic rituals are described in detail in these reports. In addition, the reports of this embassy delegation provide comprehensive and wide-range information to the researchers about the periphery of Turkestan khanates, trade routes to India and the situation of Russian prisone.
\end{abstract}

Key Words: Tsarist Russia, Bukhara Khanate, Hive Khanate, Boris Pazuhin, Russian prisoners

\section{Giriş}

Rus Çarlığının 1552 Kazan ve 1556'da Astarhan'1 istila edişinden sonra Türkistan'a yaklaşımı derinlik kazanmaya başlamıştır. Rusya'nın Doğu politikasının omurgasını belirleyen I. Petro döneminden çok önce Türkistan bölgesine keşif amaçlı pek çok devlet görevlisi gönderilmiştir. Bölgeye ilk gidenler; tüccarlar, seyyahlar ve Çar'ın yakın hizmetlileri olmuştur. 
Ruslar için iktisadi bakımdan önem taşıyan bu bölge keşfedilmeyi bekleyen eşsiz bir coğrafyaydı. Bu nedenle bu topraklara ayak basan Rus Çarlığı temsilcileri bölgedeki her ayrıntıyı Çarlığa sunacakları raporlara yansıtmışlardır. ${ }^{1}$ Rus Çarlı̆̆ 1 ile Buhara Hanlığ arasındaki ilk diplomatik bağlantıy1 1557'de İngiliz tüccar Anthony Jenkinson sağlamıştır. Türkistan'da geçirdiği süre zarfında bölge hakkında not tutan Jenkinson, Türkistan'ın siyasi, iktisadi ve kültürel durumuna dair önemli bilgileri günümüze ulaştırmıştır. ${ }^{2} \mathrm{Bu}$ ilk temas sonrası Rus Çarlığı ve Türkistan Hanlıkları arasındaki münasebetler uzun bir müddet durağan seyretmiştir. Ancak Buhara Hanı İmamkulu ülkesinin ekonomik çıkarları doğrultusunda Rus Çarı I. Mihail Fedoroviç'e elçi göndermesi ilişkilerin yeniden başlamasını sağlamıştır. Buhara Hanından Türkistan bölgesinde bulunan Rus esirlerin serbest bırakılması hususunda kolaylık sağlanacağı, sözünü alan Çar, 1620'de İvan Daniloviç Hohlov'u Buhara'ya göndermeye karar vermiştir. Rus elçisi kendisine verilen talimatlar çerçevesinde bölgede temas kurmuş; 44 esirin serbest bırakılmasını sağlamıştır. İlk dönem gerçekleşen ziyaretlere ait raporlardaki tasvirler zayıf olsa da 1620-22 tarihli Hohlov'un raporu elde edilen sonuçlar bakımından önemlidir. Bu ilk temaslardaki raporlarda Türkistan hakkında detaylı bir anlatıyı bulmak mümkün değildir. ${ }^{3}$ İ. H. Hohlov ve maiyeti Türkistan Hanlıkları nezdinde tefrişat kuralları gereğince karşılanmamasına rağmen bazı Rus esirlerinin serbest kalmasını sağladığı için kısmen başarılı bir misyon temsilcisi olarak görülebilir. Türkistan bölgesi ile siyasi ve ticari olarak ilişkileri ilerletmek isteyen Çarlık yönetimi Hohlov sonrası bölgeye 1642'de Onisim Gribov başkanlığında yeni bir elçilik heyetini göndermiştir. Ancak bu elçilik heyetinin raporları günümüze ulaşmamıştır. ${ }^{4}$

Çar Aleksey Mihayloviç (1645-1676) döneminde Türkistan ile yeniden temas kurulması için harekete geçilmiştir. Buhara, Hive, Belh ve Hindistan'a gönderilmesi öngörülen elçilik heyetinin başına üvey kardeşler Boris ve Semen Pazuhin seçilmiştir. ${ }^{5} \mathrm{Bu}$ iki kardeşe verilen talimatlarda Türkistan bölgesi dişında çevre ülkeler ile de ilişkilerin geliştirilmesi yönünde taleplerin bulunması, bu misyonun uluslararası hüviyet kazanmasını sağlamıştır. ${ }^{6}$

Çarlığın doğu siyasetinin gerçekçi temeller üzerine oturtulmasının ilk safhası tanıma sürecidir. Dolayısıyla bölgeye gönderilen elçilik heyetlerinin tuttuğu notlar, Çarlığın kendisini Türkistan Hanlıklarına karşı konumlandırmasını sağlayacak, haliyle bu farkındalık ve bilgi birikimi işgal sürecini de hızlandıracaktı. Bu çalışma XVII. Yüzyılın ilk yirmi yılında iç

\footnotetext{
${ }^{1}$ Aleksandr Kolesnikov, Mariya Matveyeva, Rus Seyyahların Gözüyle Orta Asya, Çeviri Bilim Yay., İstanbul 2019, s. 9.

${ }^{2}$ Jenkinson'un seyahat raporları için bkz., Early Voyages and Travels to Russia and Persia by Antony Jenkinson and Other English Menm with Some Account of the First Inter course of the English with Russia and Central Asia by way of the Caspian Sea, Vol. I., Edited by: E. Delmar Morgan and C.H. Coote, Printed fort he Hakluyt Society, London (t.).

${ }^{3}$ N.İ. Veselovskiy, Ivan Daniloviç Hohlov, S. Petersburg, 1891; Sbornik Knyazya Hilkova, "Stateynıy Spisok Posolstva v Buhariyu Dvoryanina İvana Hohlova” S. Petersburg 1879, s. 388-439.

${ }^{4}$ Jukovskiy, Snoşeniya Rossii s Buharoii Hivoy za Poslednee Trehsotletıe, Petrograd 1915, s. 23-27.

${ }^{5}$ Buhara Hanlığına gelen Rus diplomatlar için bkz., Selim Serkan Ükten, “16-18. Asırlarda Buhara Hanlığı'na Gelen Batılı Seyyahlar ve Seyahatnameleri”, Eskişehir Osmangazi Üniversitesi Sosyal Bilimler Dergisi, S. 18(2), Aralık 2017, s.137-164; Dinçer Koç, "XVI.-XIX. Yüzyıllarda Buhara Hanlığı'na Gelen Rus Diplomat ve Askerleri” TDA, C. 115, S. 227, Mart-Nisan 2017, s. 61-90.

${ }^{6}$ Ron Sela, "Seventeenth-Century Russian Diplomatic Mission to Central Asia", (edited by Nile Green), Writing Travel in Central Asian History, Bloomington and Indianapolis: Indiana University Press, 2013, s. 80-84.
} 
karışıklıklar nedeniyle bir yıkımla karşı karşıya kalan, Kazan, Astarhan gibi imparatorluğun uzak noktalarında yönetim zafiyetleri yaşayan Çarlığın, doğu istikametinde genişleme dinamiklerini elçilik heyeti üzerinden ele almaktadır. ${ }^{7}$

\section{Pazuhin Kardeşler}

Türkistan'a gönderilen bu yeni elçilik heyeti önceki elçilik misyonlarına nazaran daha özenle seçilmiştir. Elçiliği maiyetinin seçimi, onlara verilen talimatların ayrıntıları bu durumu kanıtlar niteliktedir. Elçiliğe başkanlık etmesi için görevlendirilen Pazuhin kardeşlerin bu göreve ne kadar uygun oldukları ve Çar'ın güvenini kazanmaları geçmişlerinde gizlidir. Pazuhin kardeşler hakkındaki kısıtlı bilgiye rağmen onların bu misyona uygunluğu kaynaklardan tespit edilebilir. Pazuhin kardeşler hakkındaki en detaylı bilgileri Lenin Kütüphanesi'nde bulunan ve kronolojik olarak XVII. yüzyıldan 1914'e kadar Rus soyluları hakkında bilgi veren arşiv kayıtlarında bulmak mümkündür. ${ }^{8}$ Bu kayıtlara göre Pazuhinlerin XV. yüzyıla kadar Mstislav' da ${ }^{9}$ yaşadığı bilinmektedir. Prens Vasiliy İvanoviç'e hizmet etmek için Kostroma ${ }^{10}$ şehrine taşınan aile iki yüzyıl sonra Mstivlav'da toprakların verimsizliğinden şikâyetçi olarak Simbirsk bölgesinde yaşamaya karar vermiştir. Pazuhin ailesi Moskova'da iç karışıklık dönemlerinde Çarlık yönetiminin yanında yer almıştır. Hatta Polonyalılar ve sahte Dimitri'ye karşı verilen mücadelede aileden pek çok kişi ön saflarda bulunmuştur. Çarlık yönetimine destek olmaları Moskova çevresinde toprak sahibi olmalarını sağlamıştır. Daha açık bir ifade ile Pazuhin ailesi hizmet sınıfından (slujilie lyudi) soyluluk sınıfına geçmiştir. Zira Çarlık yönetimi tarafından kendilerine arazi/pomest ${ }^{11}$ tahsis edilmiştir. ${ }^{12}$

Türkistan'a gönderilecek olan Boris ve Semen Pazuhinlerin Moskova yönetimine daha önce hizmet edip etmediği konusunda kaynaklar ketumdur. Pazuhinlerin sekiz bin sayfalık arşiv kayıtlarını inceleyen Rus araştırmacı Oşanina'nın, bu iki kardeşin geçmişi hakkında bilgi vermemesi de onların daha önce resmi bir görevde bulunmadığı tezini güçlendirmektedir. Ancak ailenin Çar’a karşı yüzyıllardır sadakatle hizmet etmeleri, elçilik heyetine önderlik yapmalarının önünü açmıştır. Semen Pazuhin Türkistan seyahati sonrası Astarhan yakınlarındaki Kordsun ve Tagaev bölgesinde askerlerin koordinasyonunu sağlamış ve onlara

\footnotetext{
${ }^{7}$ Geoffrey Hosking, Rusya ve Ruslar Erken Dönemden 21. Yüzyıla, İletişim Yay., İstanbul 2011, 201-209.

${ }^{8}$ E. H. Oşanina, "Hozyaystvo Pomeşikov Pazuhinıh v XVII-XVIII Vekah", S. 7, Voprosu İstori, 1956, s. 84-92.

${ }^{9}$ Mstislav, Doğu Belarus, Mogilev bölgesinde bulunan bir kasabadır.

10 Kostroma, Rusya'nın batı kesiminde bulunan ve Kostroma Oblastı'nın merkezindedir. İdil Nehri kıyısında, Moskova'nın $320 \mathrm{~km}$ kuzeydoğusunda yer alır.

11 Pomest, VI. ve VII. yüzyılda İslam devletlerinde süvari ordularının fetih sonrası geniş topraklarını kontrol etmelerini sağlayan iktaya ve genişleme döneminde Osmanlı İmparatorluğu tarafından kullanılan tımara benzemektedir. Bütün bu sistemlerde yeni elde edilen toprak, asker yetiştirme şartıyla sadık bir hizmetkâra verilmekteydi. III. İvan Novgorod'dan sürgün ettiği zengin boyarlarınki de dahil üç milyon acresa (bir acre 0,404 hektara eşit) yakın tarım alanı elde etti. Bu araziler askeri ve sivil hizmetlere karşılık dağıtıldı. Bu kadar hızlı genişleyen, iletişim ve emir komuta ağı gerektiren bir devlet için toprak kaynağı yaratabilmek çok önemliydi. Toprakların aktarımı, Moskova'nın büyük prenslerine yeni toprakları sınırlarına katma ve yönetme, yeni çalışanları çekme ve onlara bağışta bulunma, ayrıca onların büyümekte olan büyük ordularını finanse etme olanağı veren ve hizmet esasına dayalı olan pomest sisteminin temelini oluşturdu. Geoffrey Hoskıng, Rusya ve Ruslar Erken Dönemden 21. Yüzyıla, Çev. Kezban Acar, İletişim Yay., İstanbul 2011, s. 128-132; Ayrıntılı bilgi için bkz., V. B. Kobrin "Stanovlcnie Pomesnoi Sistemu" Isttroceskie Zapiski 105, 1980, s. 150-195.

${ }^{12}$ E. H. Oşanina, "Hozyaystvo Pomeşikov Pazuhinıh v XVII-XVIII Vekah”, S. 7,Voprosu İstori, 1956, s. 85.
} 
önderlik etmiştir. 1678-1680 yıllarında Romodanovski, Çerkasskiy ${ }^{13}$ ve Golitsin komutasındaki alaylarda görev almıştır. Son olarak ise 1707 'de İsveç esirlerinin Nijni-Novgorad'a taşınmasına eşlik etmiştir. Semen Pazuhin neredeyse 40 yıl Çar'a hizmet etmiştir. Semen Pazuhin'in kişisel yazışmalarından onun çok sayıda mülke sahip olduğu ve bu uğurda yeni topraklar elde etmek için mücadele ettiği anlaşılmaktadır. Oşanina, Semen Pazuhin'in zorla ve usulsüz olarak çok sayıda araziye el koyduğunu, neredeyse mevcut arazilerini bu yöntemle yedi katına çıkardığını belirtmektedir. Zorla kazandığı bu toprakları elde tutma hırsı Semen'i Türkistan içlerine yapılacak uzun yolculuğa itmiş olmalıdır. ${ }^{14}$ Ayrıca Semen'in kıyafet konusunda koleksiyoner titizliğine sahip olması ve ipek ticareti yapmak istemesi, ipeği ile ün salmış olan hanlıklara gitme konusunda Çarlık yönetiminin doğru bir karar verdiğini göstermektedir. ${ }^{15}$ Arşiv kayıtlarında Semen hakkında daha fazla bilgi olmasına rağmen elçiliğe Boris Pazuhin'in başkanlık ettiği iki kardeşe verilen talimatnamelerden anlaşılmaktadır. Boris Pazuhin elçilik görevi sonrasında Çarlık hizmetinde bulunmuş 1679 'da Kırım'a elçi olarak gönderilmiş ancak burada Kossaklar tarafindan öldürülmüştür. ${ }^{16}$

\section{Pazuhin Kardeşlerin Türkistan Misyonunun Çerçevesi}

Rus Çarlığının Hive ve Buhara'ya diplomatik temas kurulması için yeni bir elçilik heyetini görevlendirmesinin arkasında, iktisadi, ticari ve askeri çok sayıda sebep sayılabilir. Ancak bu misyonun kuvveden fiiliyata geçişinde en önemli tetikleyici unsur Hive ve Buhara'da bulunan Rus esirlerin kurtarılması hususunda Çarlı̆̆ın muhtelif bölgelerinden gelen çok sayıda mektup olduğu söylenebilir. Bilhassa Astarhan Valisi boyar İvan Semenoviç Prozrovski’ye teslim edilen 3 mektup, bu misyonun şekillenmesinde etkili olmuştur. Esirlerin verdiği ilk dilekçede Kazan, Ufa ve Sibirya gibi bölgelerden çok sayıda Rus vatandaşının Kalmuk, Nogay ve Başkurtlar tarafından köylerinden, kasabalarından ve şehirlerinden kaçırılarak esir pazarlarına satıldıkları belirtilmiştir. ${ }^{17}$ Esirlerin ikinci mektubunda ise abartılı bir biçimde Ürgenç, Buhara ve Belh'de 1200 esirin olduğu ve Çar'ın kendilerini bu esaret hayatından kurtarması talep edilmiştir. ${ }^{18}$ Çarı Ortodoks tebaasını kurtarmak için harekete geçiren son mektup, her üç mektupta da imzası olan rahip Afanasii İvanov tarafından yazılmıştır. Bu mektupta bölgede bulunan esirlerin müşkül durumlarından bahsedilerek zorla Müslüman yapıldıkları ifade edilmiştir. ${ }^{19}$ Pazuhinlere verilen talimatnamede bu üç mektubun ayrıntıları ile belirtilmesi ve Ortodoks esirlerin ne pahasına olursa olsun kurtarılması hususundaki beyanatlar, bu misyonun dini ve siyasi çerçevede gerçekleşeceğini göstermektedir.

\footnotetext{
${ }^{13}$ Ayrıntılı bilgi için bkz., Murat Özkan, "Bekoviç Gibi Kaybetmek: Aleksandr Bekoviç Çerkasskiy’in 1717 Hive Seferi", İstanbul 2018, MUTAD, C. V. s. 93-111.

${ }^{14}$ Robert Crummey, Aristocrats and Servitors: The Boyar Elite in Russia, 1613-1689. Princeton, New Jersey: Princeton University Press, 1983, s.109-124.

${ }^{15}$ E. H. Oşanina, s. 85-90.

${ }^{16}$ V.V. Barthold, Rusya ve Avrupa'da Oryantalizm, Çeviren: Kaya Bayraktar, Ayşe Mera, Küre Yayınları, İstanbul 2004, s. 25.

${ }^{17}$ Bu mektup, Maksimko, Afanasii Ivanov, Mikitka Dorofeev ve Zabrodin imzalıydı. Bkz., A. N. Truvorova, "Nakaz Borisu i Semenu Pazuhinım, Poslannım v Buharu, Belh i Yurgenç 1669" Ruskaya Istoriçeskaya Biblioteka, Arheografiçeskoy Komissii, S. Petersburg 1894, s. 22-23.

${ }^{18}$ Mekup Vaska ve Afanasii İvanov tarafından yazılmıştır. Bkz., "Nakaz Borisu i Semenu Pazuhinım, Poslannım v Buharu, Belh i Yurgenç 1669", s. 23.

19“Nakaz Borisu i Semenu Pazuhinım, Poslannım v Buharu, Belh i Yurgenç 1669"s. 24.
} 
Pazuhinlerin Türkistan misyonunun kavramsal çerçevesi Çar tarafından yurtdışına çıkan resmi görevlilerin elçilik ritüellerini nasıl yürütmesi gerektiğine dair nakaz olarak adlandırılan talimatnameler etrafında şekillenmiştir. Bu talimatnamelerin en önemli özelliği Çar'a itaatti. Yani elçilik heyeti tamamen nakazda yazan bilgilere göre hareket etmeliydi. İlk nakazlarda bölgenin kültürel ve etnografik yapısı hakkında bilgi talebinin yerine elçinin sadece yöneticiler arasında pasif bir aracı olması isteniyordu. Ancak nakazlarda elçilik heyetinin ne yapması gerektiği yazarken maruz kaldıkları tepkilere karşı nasıl davranmaları gerektiği yazmamaktaydı. Bu nedenle elçilerin bu tür durumlardaki siyasi manevraları onların özgürlük alanını oluşturuyordu. Zaten elçilik heyetinin başarı kıstasını da bu özgürlük alanları belirliyordu. ${ }^{20}$

Rus Çarlığının Türkistan Hanlıkları ile kurmak istediği diplomatik ilişkiler erken dönem diplomasi ritüelleri ile uyumluydu. Elçiliğin, Buhara, Belh ve Hive'de bir müddet kalması ümit ediliyordu. Güney komşularını merak eden Çarlık yönetimi dönem itibariyle yaygın olan kısa süreli diplomatik eylemi tercih etmekteydi. Elçiliğin Türkistan misyonunu oluşturan belli başlı görevleri vard1. Bunlardan ilki Türkistan'da bulunan Rus esirlerin özgürlüklerine kavuşturulması ve Hindistan'a giden yol hakkında bilgi edinmekti. İpek yetiştiriciliği yapan Hive ve Buharalı tüccarlar ile ilişkileri geliştirmek suretiyle ticari girişimlerde bulunmak ve Türkistan Hanlıklarının, Hindistan, İran ve Osmanlı Devleti ile ilişkileri hakkında bilgi edinmenin yanı sıra hanlıkların diplomasi ritüellerinin neler olduğunun öğrenilmesi de verilen görevler arasında yer almaktaydı. Yine bölgede ticari faaliyette bulunacak bir tüccarın takip etmesi gereken yol ve vergilerin tespiti misyonun amaçlarındandı. Bu görevler dışında Moskova yönetimine isyan eden Stenka Razin ${ }^{21}$ ve takipçileri hakkında bilgi toplanması da istenmişti. Pazuhin kardeşlere tebliğ edilen görevlerden en ilginci ise Ortodoks inancinda önemli bir yeri olan Aziz Simon'un kemikleri hakkında bilgi toplayarak Moskova'ya getirmek $\operatorname{vard}_{1}{ }^{22}$

Nakazdaki talimatlar Rus Çarlığının bu seyahatten beklentisi içeriyordu. Pazuhinlere verilen talimatnamede öncelikle Rus Çarı Aleksey Mihaloviç'in unvanları sırasıyla doğru bir şekilde okunması istenmiştir. İki devlet arasındaki diplomatik yazışmalarda bu unvanlar çok önemliydi. Osmanlı sultanlarının Akdeniz, Karadeniz, Rumeli ve muhtelif bölgelerin hâkimi şeklinde devam eden unvan zincirinin benzeri Rus Çarlığı için de geçerliydi. Bu unvanlardaki bölge isimleri, iletişim olanaklarının hayli kısıtlı olduğu bir dönemde komşu ülkelere Çarlığın siyasi, ekonomik ve askeri gücünü dikte etmek ve imparatorluğun ulaştığı sınırları göstermekti. Unvan sıraları özenle seçilmişti. Çar'ın unvanlarında öncelikle Moskova, Kiev Vladimir ve Novgorod gibi eski Rus şehirlerinin zikredilmesi ve hemen akabinde Çarlığın emperyal gücünü sergileyen

\footnotetext{
${ }^{20}$ Ayrıntılı bilgi için bkz., Avis Bohlen, "Changes in Russian Diplomacy under Peter the Great," Cahiers du Monde Russe et Sovietique, Vol. 7, No. 3, 1966, s. 344-345.

${ }^{21}$ Stenka Razin, Çarlık idaresine karşı isyan ederek, Yayık nehri üzerinden Bakü’ye gelmiş ve oradan da İran'a ulaşmıştır. 1667'de Kossakların lideri olan Stenka Razin önderliğindeki grup Hazar denizini aşarak İran üzerine başarılı bir deniz seferi düzenlediler ve evlerine bir sürü değerli ganimetle döndüler. Sonuç olarak Razin eski ve yeni tüm Kosaklar içerisinde popüler lider haline geldi. Kazandığı zaferle Moskova'ya karşı etkin bir savaş planı tasarlamaya koyuldu. Ancak iç işlerinde istikrarı kısa sürede sağlayan Çarlık yönetimi Razin'in direnişini kırmış ve onu yakalarayak 1671'de Kızıl Meydan'da asmıştır. Vernadsky, Rusya Tarihi, s. 175-176.

${ }_{22}^{2}$ M. S. Anderson, The Rise of Modern Diplomacy, 1450-1919. New York 1993, s. 47-48; Ron Sela, "SeventeenthCentury Russian Diplomatic Mission to Central Asia”, s. 80-81.
} 
yeni elde ettiği Kazan, Astarhan ve Sibirya'nın takip edilmesinin çok derin anlamlar taşıdığı kuşkusuzdur. Zira Çar için askeri zaferden çok öte anlamlar taşıyan bu bölgeler İslam ülkeleri üzerindeki nüfuzu da vurguluyordu. ${ }^{23}$

Çar, Pazuhin kardeşlere verdiği nakaz ile Türkistan bölgesindeki hanlara imparatorluğunun kudretini göstermek istiyordu. Bu nedenle Pazuhin kardeşlere nakazda elçiliğin nasıl kabul edilmesi gerektiği belirtilmiştir. Buna göre Rus elçilik heyeti kalabalık üst düzey bir maiyet ile karşılanmalı ve Han elçilik heyetini diğer elçi ve görevliler olmadan yalnız huzuruna kabul ederek başlığını çıkararak selamlamalı ve Çar'ın sağlığını sormalıydı. ${ }^{24}$ Buna karşın Rus elçiliği yerel geleneklere saygı göstermeli ve diplomasi kaide ve kurallarına uyma noktasında özen göstermeliydi. ${ }^{25} 1492$ yılında Osmanlı Sultanı Beyazıd'ın huzuruna çıkan ilk Rus elçisi Pleşçeyev'in hiçbir diplomasi kuralına uymaksızın hareket etmesi ve bunun sonucunda diplomatik krize sebep olduğu düşünüldüğünde Çarlığın diplomatik ritüellerde epey yol kat ettiği açıktı. ${ }^{26}$ Hanlıkların elçilik heyetine iaşe, rehber sağlaması ve onlardan herhangi bir sebeple vergi almaması da nakazda belirtilmişti ${ }^{27}$. Çar'ın bu taleplerdeki 1 srarı kendi imparatorluğunun ne kadar önemli olduğunu göstererek Hanlıkların ona itibar etmelerini sağlamaktı. Dolayısı ile Rus elçisinin konumunun hemen Han'ın yanında ve karşısında olması gerekliliği nakazdaki ince ayrıntılar arasındadır. ${ }^{28}$

Pazuhin kardeşler ve maiyetinin Türkistan’a ulaşması için üç ana güzergâh belirlenmiştir. En hızlı ve kısa güzergâh Astarhan'dan Hazar Denizi'ne oradan Mangışlak yarım adasındaki Karagan'a ve oradan Hive'ye ulaşan dört haftalık yoldu. Ancak bu güzergâh üzerindeki unsurlar tehlike arz ettiğinden çok da güvenli değildi. İkinci yol ise Astarhan'dan Yayık'a ardından Yemba Nehri'nden Hive'ye ardından Buhara'ya ulaşan tahmini dokuz hafta süren rotaydı. En uzun yol ise Astrabat yoluyla Hazar Denizi oradan Meşhed ve Merv'in güney batısından Buhara'ya ulaşan on dört haftalık güzergâht ${ }^{29}$. Rus hükümeti Türkistan yolculuğunun zorluğunun farkındaydı. Bu nedenle elçiliğin istedikleri güzergâhı seçme hususunda onları serbest bıraktı. Açıkçası ilk rota seyahat süresi kısa olduğu için tercih edilebilirdi. Ancak elçiliğin Astarhan'a ulaştıktan sonra Türkmen bölgelerinden geçmesi tehlike arz ediyordu. Zira Hohlov'un elçiliği döneminde bu tehlike tecrübe edilmişti. ${ }^{30}$ Dolayısı ile elçilik en güvenli yol olan kara yolu ile Mangışlak Yarımadasından Hive'ye ulaşan yolu tercih etti. Kalmuk hakimiyet sahasından geçen bu güzergâh daha güven veriyordu. Zira o dönemler

\footnotetext{
${ }^{23}$ Michael Khodarskovsky, Not By Word Alone: Missinary Policies And Religions Conversion in Russia, 1550-1780, s. 1-2; Jennifer Johnson, The Pazukhin Embassy: A Look at Political Portrayal of Power between Seventeent-Centuy Russia and the Uzbek Khanates, İndiana University, Mayıs 2010, s. 18-19; "Nakaz Borisu i Semenu Pazuhinım, Poslannım v Buharu, Balh i Yurgenç 1669”, s. 5.

24، Nakaz Borisu i Semenu Pazuhinım, Poslannım v Buharu, Belh i Yurgenç 1669, s. 4.

25 "Nakaz Borisu i Semenu Pazuhinım, Poslannım v Buharu, Belh i Yurgenç 1669”, s. 38-42.

${ }^{26} \mathrm{~V}$. Teplova, Russkie Predstavitelli v Tsargrade 1496-1891, İstoriçeskiy Oçerk, S. Petersburg 1891, s 3; Nikolay Mihayloviç Karamzin, Ístoriya Gosudarstva Rossiyskogo, I, Moskova 2002, s. 972-973.

27“"Nakaz Borisu i Semenu Pazuhinım, Poslannım v Buharu, Belh i Yurgenç 1669”, s. 3

28"Nakaz Borisu i Semenu Pazuhinım, Poslannım v Buharu, Belh i Yurgenç 1669”, s. 29.

29"Nakaz Borisu i Semenu Pazuhinım, Poslannım v Buharu, Belh i Yurgenç 1669”, s. 21.

30 1620-22 yılları arasında Buhara'ya diplomatik ilişkiler kurmak için giden İvan Hohlov, Hazar Deniz'inden müteakip yaptığı deniz yolcuğu sonrası Türkmenlerin saldırısına uğramıştır. Hohlov ve maiyeti Türkmenler ile çatışmış bazı adamlarını kaybetmiştir. Rus elçilik heyeti Türkmen grubundan ancak rüşvet vererek kurtulabilmiştir. Sbornik Knyazya Hilkova, (1879) "Stateynıy Spisok Posolstva v Buhariyu Dvoryanina İvana Hohlova", S. Petersburg 1879, s. 389-390.
} 
Kalmuklar ile Rus Çarlığı arasındaki ilişkiler iyiydi. ${ }^{31}$ Ayrıca Kalmuk Tayçisi ${ }^{32}$ onlara rehberlik etme sözü de vermişti ${ }^{33}$. Çar, Pazuhin kardeşlerin Türkistan yolculuğu öncesi geçeceği güzergâhta bulunan şehirlerin yöneticilerine hitaben mektuplar yazmıştır. Bu mektuplarda elçilik heyetinin serbestçe seyahat etmesi, gümrük vergisi ödememeleri ve onlara iaşe sağlanması belirtilmiştir. Çar, bu emirnameler ile hem elçilik heyetinin seyahatini kontrolü altına almış hem de imparatorluğun uç sınırlarındaki hâkimiyetinin pekişmesini sağlamıayı amaçlamıştır. $^{34}$

\section{Pazuhinlerin Hive Yolculuğu ve Anuşa Han (1664?-1687) ile Görüşmeleri}

Pazuhin kardeşler, görevlerinin ilk ayağını oluşturan Hive seyahati 30 Haziran 1669'da Moskova'dan hareketle başlamıştır. Volga ve Oka nehirleri boyunca 21 gün seyahat eden Pazuhinler, 20 Temmuz'da Kazan'a ulaşmışlardır. Burada üç hafta konaklayan elçilik Volga Nehri boyunca seyahat ederek 19 Eylül'de Astarhan'a varmıştır. Elçilik heyetinin yanında Moskova'dan getirilen çok sayıda hediye ve hazineye ait değerli eşya vardı. Bu nedenle Astarhan valisi İvan Semenoviç, elçiliğin Karagan iskelesinden deniz yolu ile yapacağı yolculuğun hem sonbaharın gelmesi ile hava koşullarının kötü olması hem de Hive'ye gitmek için Türkmen bölgelerinden geçileceği için tehlike arz edeceğinden tercih edilmemesini telkin etmiştir Pazuhin kardeşler valinin bu tavsiyesine uymuş ve karayolu ile seyahat etmeye karar

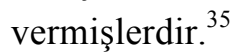

Astarhan Valisi, Çar'ın emri ile Pazuhin ve maiyetinin iaşesini sağlamak ile yükümlüydü. $\mathrm{Bu}$ nedenle vali, elçilik heyetinin tüm ihtiyaçlarını karşılamış ve onlara ayrıca 1445 ruble değerinde mors dişi vermiştir. Astarhan'daki hazırlıklarını tamamlayan elçilik heyeti yol boyunca güvenliklerinden sorumlu Kalmuk Dayçisinin gelmesi ile 10 Mart 1670'de Astarhan'dan ayrılmışlardır. ${ }^{36}$ Pazuhinler 14 günlük yolculuğun sonunda Kalmuk Dayçisinin şehri olan Kamian şehrine 3 gün uzaklıkta kamp kurmuşlardır. Elçilik heyeti Kalmuk hakimiyet alanında geçtiği topraklarda çok sayıda yerel yönetici ile tanışmış onlara hediyeler sunmuş karşılığında iaşe almıştır. 14 Mayıs'ta Pazuhinler, Amuderya'nın sağ kıyısında yer alan ve Hive topraklarındaki ilk şehir olan Kat şehrine iki günlük mesafeye kadar gelmişlerdir. Rus elçilik heyetinin sorumlusu olan Boris Pazuhin, tercümanı Mikita Medveyev'i Kat şehrine yollayarak Rus Çarlığı tarafindan görevlendirildiklerini ve elçiliğin nerede konaklaması gerektiğini bildirmesini istemiştir. Bunun üzerine Kat şehrinin güvenliğinden sorumlu Hudaverdi adlı görevli elçilik heyetinin yanına gelerek 16 Mayıs'ta onların şehre intikal etmesini sağlamıştır. Hudaverdi, elçiliği oldukça iyi karşılamış, Boris Pazuhin'e gümüş bir eyer hediye etmiştir. Pazuhinler, Kat şehrinde, bozkırda özgürce dolaşan halkın kendilerini merak ederek yanlarını geldiğini ve onlara çeşitli ikramlarda bulunduklarını ifade etmektedir. Bölgede bir süre

\footnotetext{
${ }^{31}$ Ekrem Kalan, Cungar Hanlığının Siyasi Tarihi, TTK, Ankara 2008. s. 25-28.

${ }^{32}$ Tayçi veya Taişi, Çinçe Tai-zu kelimesinden Moğol diline geçmiş olup, han veya noyanın oğlu anlamında kullanılmaktadır. Bkz, Ekrem Kalan, Cungar Hanlı̆̆ının Siyasi Tarihi, s.7.

33"Nakaz Borisu i Semenu Pazuhinım, Poslannım v Buharu, Belh i Yurgenç 1669”, s. 21; Ron Sela, "SeventeenthCentury Russian Diplomatic Mission to Central Asia”. s. 34.

34، Nakaz Borisu i Semenu Pazuhinım, Poslannım v Buharu, Belh i Yurgenç 1669”, s. 31-32.

35"Nakaz Borisu i Semenu Pazuhinım, Poslannım v Buharu, Belh i Yurgenç 1669", s. 34-35.

36 "Nakaz Borisu i Semenu Pazuhinım, Poslannım v Buharu, Belh i Yurgenç 1669", s. 35.
} 
konaklayan Rus elçilik heyeti Hive'ye ulaşmak için Kat şehrinin köylerini ziyaret etmiş yerel yöneticiler tarafından misafirperver bir biçimde karşılanmışlardır. ${ }^{37}$

18 Mayıs 1670 'de Rus elçilik heyeti, Hive önlerine geldiğinde Anuşa Han'ın iki yavasulu ${ }^{38}$ ve 100 kadar farklı kademelerden devlet görevlisi Pazuhinleri karşılamıştır. Anuşa Han'ın elçilik heyetini karşılaması için gönderdiği memurlar çok sayıda gümüş eyer, at ve elçiliğin hazinesinin taşınması için at arabasını elçiliğe hediye etmiştir. Daha önce bölgeye giden Rus elçilik heyetlerinin yaşadığı olumsuz karşılama ritüellerinin aksine iyi şekilde karşılan Pazuhin ve maiyeti bu muameleden oldukça memnun kalmıştır. Hatta Boris Pazuhin Hive Hanı Anuşa'nın hediye ettiği at ile şehre girmiştir. Hive Han'ı misafirlerini kapıda karşılamıştır. ${ }^{39}$

Rus elçilik heyetine konaklamaları için eski saraylardan biri tahsis edilmiş ve iaşeleri sağlanmıştır. Pazuhinlerin şehre girişinden 3 gün sonra Anuşa Han elçiliği huzuruna kabul etmiştir. Pazuhinler, Anuşa Han'a hediyelerini sunmak ve ziyafet vermek için Han'in memuru Hudaverdi’ye bilgi vermiştir. Ancak Hudaverdi Hive geleneklerine göre hediye ${ }^{40}$ takdiminin ahali önünde yapılması gerektiğini elçiliğe iletmiştir. Ancak Boris Pazuhin bu teklifi kabul etmeyerek Çar'ın hediyelerini sadece Han'ın huzurunda sunabileceğini ifade etmiştir. Aynı gün Boris Pazuhin, Anuşa Han'ın huzuruna çıkmak için harekete geçmiştir. Han, Boris Pazuhin'i sarayının bahçesinde ağırlamıştır. Boris’i sarayın kapısında iki yavasul karşılamış ve Han'ın huzuruna çıkarmıştır. Boris Pazuhin elçilik raporunda Anuşa Han ile görüşmesini şöyle tasvir etmektedir. Han bahçenin orta klsmında bulunan altın renginde olan bir odada uzun bir halının üzerinde tahtında oturmaktaydl. Han'in her iki tarafinda da Atalik ${ }^{41}$ olarak adlandırllan görevlilerle beraber 24 kişi duruyordu. Ayrıca Han'ın huzuruna yakın bir odanın kapısında bir yavasul ve 100 kadar Özbek görevlinin beklediği yüksek rütbeli memurlar vard.. Boris Pazuhin'e verilen emirnameye riayet eden Anuşa Han başlığını çıkartarak selam vermiş ve Çarın sağlığını sormuştur. ${ }^{42} \mathrm{Bu}$ ilk kabulde taraflar arasındaki ilk müzakere Rus esirleri meselesi olmuştur. Hatta Han'a, Çar'ın Rus esirlerinin serbest kalması hususundaki mektubu

\footnotetext{
37 "Nakaz Borisu i Semenu Pazuhinım, Poslannım v Buharu, Belh i Yurgenç 1669", s. 38.

${ }^{38}$ Türk-Mogol devletlerinde sıkça karşımıza çıkan ve Buhara ve Hive devlet teşkilatında da gördüğümüz düşük rütbeli asker olan yavasullar, çok sayıda görevi yerine getirmekle mükellefti. Bunlar arasında haberci, vergi tahsildarı, yöneticilerin gönderdiği hediyeleri dağıtımı sağlama, elçilik heyetlerini karşılama, Han ile şehzadeler arasında ilişkileri düzenleme, Han'a kabulleri sağlama gibi görevleri ifa etmekteydi. Bkz., Burton, The Bukharans: Dynastic, Diplomatic and Commercial History, 1550-1702, s. XVIII; Selim Serkan Ükten, agt, s. 107; Nurettin Hatunoğlu, "Buhara Hanlığı", Avrasya'nın Sekiz Asrı Çengizoğulları, Ötüken, s.491.

39 "Nakaz Borisu i Semenu Pazuhinım, Poslannım v Buharu, Belh i Yurgenç 1669”, s 39-40.

${ }^{40}$ Pazuhinlerin elçilik heyeti tarafından Hive Hanlığında verilen hediyeler şu şekildedir. Anuşa Han'a kırk samur kürkü, altmış ruble değerinde ipek, bir saten kaftan, çeşitli renklerde elbiseler, yarım kilo mors dişi, iki fener, üçü büyük olmak üzere 14 ayna, iki geyik derisi; Atalık makamında bulunan Gard-Khiuzh'a çift samur, Rus derisi, iki küçük ayna; Atalık Küçüm Berdu (Han'ın kayınpederi), Devlet ve Kul Memet'e bir çift samur, iki küçük ayna ve çeşitli elbiseler; Han'ın kardeşi Isnazar-Bek bir çift samur, bir kıyafet, Rus derisi ve bir küçük ayna; Tay-Berdu Mirohor, bir çift samur, Rus derisi, bir ayna; Diak, Abdülkerim, bir çift samur, elbise, Rus derisi ve küçük ayna; saraydaki görevli Farak-Bek bir çift deri, iki küçük ayna, Boris Pazuhin'e yolculuk esnasında eşlik eden Hudaverdi, çeşitli kıyafetler, ve kürk, bir fener, küçük ayna ve kumaşlar; Dvornik Uraz-Memet, elbise ve altın ayna; Dvornik Kulbaba-Ipak elbese ve küçük altın ayna. Bu hediyeler Hive devlet teşkilatında bulunan en düşük rütbeli memura kadar inmektedir. Bkz., "Nakaz Borisu i Semenu Pazuhinım, Poslannım v Buharu, Belh i Yurgenç 1669", s. 43-44.

41 Buhara ve Hive devlet teşkilatında devlet memurlarına verilen en yüksek rütbelerden biridir. Hanedan mensuplarının koruyuculuğu, yetişmesi gibi çeşitli görevlerde bulunan bu görevliler Han'ın yokluğunda hükümeti yönetebilmekteydi Bkz., Burton, The Bukharans: Dynastic, Diplomatic and Commercial History, 1550-1702, s. XII; Selim Serkan Ükten, agt, s. 81-83; Nurettin Hatunoğlu, "Buhara Hanlığı”, s. 491.

42 "Nakaz Borisu i Semenu Pazuhinım, Poslannım v Buharu, Belh i Yurgenç 1669", s. 40
} 
takdim edilmiştir. Anuşa Han bu ilk görüşmede esirlerle ilgili mesele üzerinde durmaktan kaçınmıştır. $^{43}$

Boris Pazuhin ve Anuşa Han'ın görüşmelerinden 3 gün sonra elçilik heyeti onuruna bir ziyafet verilmiştir. Bu ziyafette Boris Pazuhin, Han'a çok yakın bir yerde oturmuştur. Masada Buhara elçisi Nazar-Bek ve yanında Kalmuk elçisi Darzhan oturmaktaydı. Yemekler öncelikle Han'ın önüne getirilmiş ve gümüş kaplarda servis edilmiştir. Yemekte elçilik heyetine altın taslarda kımız da sunulmuştur. Boris Pazuhin ve Anuşa Han arasındaki bu ikinci görüşmede de esirler konusu tekrar gündeme gelmiş, Han esirlerin bölgeden ayrıldığını burada kalanların ise Kalmuk ve Başkurtlardan satın alındığını, bu nedenle onları serbest bırakmak için fidye ödenmesi gerektiğini ifade etmiştir. Ancak Han, yüksek miktarda fidye istenmiş olmalı ki Boris Pazuhin yanlarında yeterli miktarda para olmadığını, ödemenin Astarhan valisi tarafından yapılabileceğini belirtmiştir. Ancak Anuşa Han bu öneriyi kabul etmemiş ve taraflar arasındaki müzakereler daha fazla sürdürülememiştir. Yemekten sonra Boris Pazuhin, Han'ın yakın adamlarından olan atalık mevkiinde bulunan görevli ile görüşmüş, eğer esirlerin serbest bırakılmasını sağlar ise Çar'ın onu ödüllendireceğini ifade etmiştir. ${ }^{44}$ Nitekim Çar'ın verdiği talimatnameye göre eğer esirler bedelsiz bir şekilde serbest bırakılmaz ise hazineden fidyelerinin ödenmesi tavsiye edilmiştir.

Boris Pazuhin ve heyeti Hive'de istediğini alamasa da kendilerine verilen talimatnameye binaen Han'a Rus esirlerinin satılmasına aracı olunmaması hususunda Çar'ın tavsiyelerini iletmiştir. Eğer bu tavsiyelere riayet eder ise Çar'ın dostluğunu kazabilirlerdi. Ayrıca Çar, elçiliğin Buhara seyahati için iaşe ve rehberin sağlanmasını da istemiştir. Bunun üzerine Hive Han'ı Anuşa, elçiliğe yolculuk boyunca yetecek iaşe vererek Murat Bek adındaki memurunu da onlara rehber tayin etmiştir. Rus elçilik heyetinin bu isteklerinin yerine getirilmesi Moskova'nın gücünün ne kadar tesirli olduğunu da ortaya koymaktadır. ${ }^{45}$

\section{Buhara Yolculuğu ve Abdülaziz Han ile Görüşmeleri}

Pazuhin kardeşlerin Hive temasları daha önceki elçilik misyonlarının çizdiği portrelerden farklılık gösterir. Nitekim taraflar arasındaki görüşme diplomatik kaideler çerçevesinde geçmiş tefrişat kuralları kusursuz biçimde uygulanmıştır. Ancak Anuşa Hanın Rus elçilik heyetinin taleplerini tümüyle karşıladığı söylenemez. Boris ve Semen Pazuhinlerin Türkistan misyonunun bir diğer ayağını 16 ay boyunca temasta bulundukları Buhara oluşturmaktaydı. 3 Haziran'da Hive'den ayrılan heyet bir gün konaklayacakları Kank şehrine gelmiş ve ertesi gün Azarkin kasabasına ulaşmıştır. Elçiliğin Buhara Hanlığı sınırına yaklaşmasından dolayı Anuşa Han tarafından görevlendirilen rehber Murat-Bek kafileden ayrılmıştır. ${ }^{46}$ Buhara'ya yönelen elçilik heyeti 10 gün boyunca 1ssız bozkırda seyahat etmiş ve güzergahtaki ilk Buhara şehri olan Karagöl önlerine gelmişlerdir. Rus elçiliğinin tercümanı Mikita Medvedev, Rus elçilik heyeti adına Karagöl yöneticisine gönderilerek şehre giriş için izin istemiştir. Bunun üzerine Karagöl yöneticisin yavasulu ve çok sayıda tüccar elçilik heyetini karşılamıştır. 19 Haziran'da

\footnotetext{
43 "Nakaz Borisu i Semenu Pazuhinım, Poslannım v Buharu, Belh i Yurgenç 1669”, s. 39-40

44 "Nakaz Borisu i Semenu Pazuhinım, Poslannım v Buharu, Belh i Yurgenç 1669", s. 49-41.

45 "Nakaz Borisu i Semenu Pazuhinım, Poslannım v Buharu, Belh i Yurgenç 1669", s. 43.

46 "Nakaz Borisu i Semenu Pazuhinım, Poslannım v Buharu, Belh i Yurgenç 1669”, s. 43.
} 
Karagöl'e intikal eden Rus elçilik heyetini şehrin yöneticisi Mama Demid Bek sarayında ağırlamış ve onlara iaşe temin etmiştir ${ }^{47}$. Ayrıca Karagöl yöneticisi, Rus elçilik heyetine Abdülaziz Han'ın, Belh yöneticisi kardeşi Sübhan Kulu ile savaş halinde olduğunu bu nedenle Hanın Karşı şehrinde karargâh kurduğunu söylemiştir. ${ }^{48}$ Şehirden ayrılan Pazuhinler 22 Haziran'da Saltan köyü mevkiine ulaşmışlardır. Burada elçilik heyetini yavasul Timur-Bek karşılamıştır. Bu sırada Buhara Hanlığında görevli Taşbulat-Biy elçilik heyetinin bulunduğu köye gelerek, onları Hanlığın merkezine götürmek için harekete geçmiştir. Buhara'da Pazuhin ve maiyetini, 200 kişiden oluşan bir heyet oldukça gösterişli biçimde karşılamıştır. ${ }^{49}$ Rus elçilik heyetinin tefrişat kuralları gereğince 3 günlük iaşeleri hemen sağlanmıştır. Buna göre mehter $^{50}$ adlı görevli $72 \mathrm{~kg}$ pirinç, 40 somun ekmek, 5 kenevir yağı, $32 \mathrm{~kg}$ üzüm, elma, kavun, sirke ve soğanı elçiliğe teslim etmiştir. ${ }^{51}$ Ayrıca elçilik heyetine konaklamaları için eski saray tahsis edilmiş, saraydaki odalar özenle hazırlanarak kışın sıcak olması için kürkler ve halılarla donatılmıştır. Buhara yönetiminin Rus elçilik heyetine yeterli miktarda iaşe sağladığ 1 anlaşılmaktadır. Zira daha önce Türkistan şehirlerinde bulunan Rus elçileri ile karşılaştırıldığında heyetin iaşesi oldukça makul bir orandadır. Ancak tüm bu ilgi ve alakaya rağmen Rus Çarlığının kudretini her alanda göstermek isteyen Boris Pazuhin kendilerine tedarik edilen iaşeyi oldukça yetersiz bulmuştur. Aslında Boris elçilik heyetine yetecek kadar yiyecek aldığının farkındaydı. Ancak Abdülaziz Han'ın şehirde olmayışı ve daha önceki Rus elçilik heyetlerinin tecrübeleri de dikkate alındığında Han'ın adamlarının rüşvet ve benzeri isteklerini bu şikâyetle ve memnuniyetsizlikle engellemek istiyordu. Nihayetinde bu siyasetinde başarılı olduğu da görülmektedir. Nitekim çok geçmeden elçiliğin memnuniyetsizliğini duyan Abdülaziz Han, Boris Pazuhin ve maiyeti ile ilgilenmesi için adamlarından Malay-Kaysar's görevlendirmiştir. Elçilik heyeti ile görüşen Malay-Kaysar, Abdülaziz Han'ın en kısa zamanda iaşe sıkıntısını çözeceğini bildirmiş̧ir. Hatta normalde yabancı misafirlerin katiyen sokulmadığ 1 Saray bahçesinde elçilik heyetinin dolaşmasına izin verilmiştir. Çok geçmeden de 8 gün yetecek iaşe Pazuhin ve ekibine teslim edilmiştir. ${ }^{52}$ Aynı dönemlerde Moskova'ya giden Buhara elçilik heyetinin iaşesi ile karşılaştırıldığında Pazuhinlere iki kat daha fazla iaşe sağlandığı tespit edilebilir. ${ }^{53}$

Abdülaziz Han, Rus elçilik heyetinin Buhara'ya ulaşmasından 6 ay sonra şehre gelmiştir. Han'ın şehre intikalinden sonra Iltizer adlı bir memur Boris Pazuhin'e Han'ın huzuruna çıkabileceklerini söylemiştir. Ayrıca Boris'e Han'ın atlarından birini vererek ona daha önce hiçbir elçilik heyetine böyle bir iltimas tanınmadığının altını çizmiştir. Rus elçilik heyeti Han'ın şehre dönüşünden 2 gün sonra 30 Haziran'da Han'ın huzura çıkmak için harekete geçmiştir. Boris Pazuhin ve maiyeti saraya ulaştıklarında onları Malay-Bek karşılamış ve atlarını dışarda bırakmalarını istemiştir. Saraya giren Boris Pazuhin'i öncelikle çeşitli

\footnotetext{
${ }^{47}$ Karagöl yöneticisi, Boris Pazuhin ve maiyetine iki gün boyunca yetecek olan buğday, siker, tereyağl, çilek ve kavun temin etmiştir. Bkz., Nakaz, s. 45.

48 "Nakaz Borisu i Semenu Pazuhinım, Poslannım v Buharu, Belh i Yurgenç 1669", s. 45.

49 "Nakaz Borisu i Semenu Pazuhinım, Poslannım v Buharu, Belh i Yurgenç 1669”, s. 45-46.

${ }^{50}$ Buhara devlet teşkilatında bağış toplayan, mülklerin satışı sağlayan düşük rütbeli bir memur. Bkz., Burton, The Bukharans: Dynastic, Diplomatic and Commercial History, 1550-1702, s. XIV.

51 "Nakaz Borisu i Semenu Pazuhinım, Poslannım v Buharu, Belh i Yurgenç 1669", s. 46.

52 "Nakaz Borisu i Semenu Pazuhinım, Poslannım v Buharu, Belh i Yurgenç 1669", s. 47.

53 Burton, Audrey, The Bukharans: Dynastic, Diplomatic and Commercial History, 1550-1702, s. 294.
} 
kademelerden yaklaşık 100 kişilik bir heyet karşılamıştır. Han'ın huzuruna çıkmadan önce Boris Pazuhin bu kalabalık grup ile beklemiş ve onların sorularını cevaplamıştır. Buna göre elçiden Rus Çarlığının, Kırım Hanlığı, Osmanlı Devleti ve Safevi Devleti ile ilişkilerinin ne durumda olduğunu açıklaması istenmiştir. Boris Pazuhin, Çarlığın Türk Sultanı, Safevi Şahı ve Kırım Han'1 ile ilişkilerinin oldukça iyi olduğunu ifade etmiştir. Nogay ve Kazak bölgeleri üzerinde ise Çarlığın güç tesis ettiğini belirtmiştir. Daha sonra Buhara Hanının Divanbegi ${ }^{54}$ Magamet Mazar-Biy ile görüşen Boris Pazuhin, Çar'ın mektubunu iletmesi için ona teslim etmiştir. Bu sırada Han'ın korumasından sorumlu Iltizer, Rus elçilik heyetinin Han'ın huzuruna çıkabileceğini onlara bildirmiştir. ${ }^{55} 30$ Aralık'ta yapılan görüşmede Pazuhin'e verilen talimatnamelere uygun bir şekilde diplomasi kaideleri yerine getirilmiş, Han, Boris Pazuhin'i huzuruna yalnız kabul etmiş, başlı̆̆ını çıkararak elçiliği selamlamış, sağında oturmasına izin vermiş, Çar'ın sağlık, sıhhat ve afiyetini sormuştur. Abdülaziz Han ile baş başa kalma ayrıcalığını yakalayan Boris, Han ile saray bahçesinde bir süre yürüme firsatına da erişmiştir. Buna karşılık Boris de Buhara resmi ritüellerini takip etmekten beis duymamıştır. $\mathrm{Bu}$ ilk görüşmede Abdülaziz Han elçilik heyetinin yolculuğu hakkında bilgi edinmiş buna mukabil Boris ise Hive'de olduğu gibi Rus esirlerinden bahis açmış fakat Han'dan herhangi bir cevap alamamış dolayısıyla bu buluşma Rus tarafı için sorunsuz ama verimsiz bir biçimde sonlanmıştır. ${ }^{56}$

Buhara'daki diplomatik ilişkileri yürüten Boris, Han'ın memurları ile de görüşmeler yapmıştır ${ }^{57}$. Bu görüşmelerde Boris hanlık hakkında bilgi toplarken, Hanlık memurları da Ruslara yönelik meraklarını gidermeye çalışmıştır. Abdülaziz Han'ın üst düzey memurları ile Rus esirler konusunu da müzakere eden Boris Pazuhin, esirlerin Ortodoks Hristiyan oldukları için serbest kalmaları gerektiğini ifade etmiştir. Fakat Hanın memurları esirlerin artık Müslüman olduğunu bu nedenle bırakılmalarının söz konusu olmadığını belirtmişlerdir. Bunun üzerine Boris, onların zorla Müslüman olduklarını dile getirse de görüşmeden bir sonuç çıkmamıştır. ${ }^{58}$ Ardından bölgede bulunan esirler ile gizlice görüşen Boris onların defalarca kaçmaya teşebbüs ettiğini, ancak bunu başaramadıklarını, Ortodoksluğa sadık olduklarını öğrenmiştir. Esirlerin, Çar'a bağlılık bildiren mektuplarını raporuna kaydeden Boris bu raporları daha sonra Çar'a sunmuştur. ${ }^{59}$

Boris Pazuhin, Abdülaziz ile ilk görüşmesinden bir hafta sonra ikinci ziyaretini gerçekleştirmiştir. Bu görüşmede de Rus esirler meselesini gündeme getiren Boris, Han'dan tatmin edici cevaplar alamamıştır. Aslında Han, esir konusunu uzatarak hem Rus Çarlığ üzerinde güç tesis etmek hem de pazarlıklardan olabildiğince fazla kazanç elde etmek

\footnotetext{
${ }^{54}$ İlk defa Timurlu döneminde karşılaştığımız divanbegi, Buhara devlet teşkilatında oldukça çeşitli görevler ifa ettiği görülmektedir. Bunlar arasında vergi tahsilatı, mali işler, diplomasi, ordu mensubu görevlerinde bulunmaktadır. Bkz., Burton, The Bukharans: Dynastic, Diplomatic and Commercial History, 1550-1702, s. XIII; Selim Serkan Ükten, agt, s. 84-85.

55 "Nakaz Borisu i Semenu Pazuhinım, Poslannım v Buharu, Belh i Yurgenç 1669”, s. 49-50.

56 "Nakaz Borisu i Semenu Pazuhinım, Poslannım v Buharu, Belh i Yurgenç 1669" s. 49-51.

${ }^{57}$ Buhara devlet teşkilatında önemli bir unvan olan Divanbegi,ve Atalık unvanına sahip görevliler vardı. Bkz., Serkan Ükten, Buhara Hanlı̆̆ı'nın Askeri Teşkilatı (1500-1868), Ankara Üniversitesi Sosyal Bilimler Enstitüsü, Doktora Tezi, Ankara 2015, s. 84.

58 "Nakaz Borisu i Semenu Pazuhinım, Poslannım v Buharu, Belh i Yurgenç 1669", s. 54.

59 Ron Sela, "Seventeenth-Century Russian Diplomatic Mission to Central Asia" s. 82; "Nakaz Borisu i Semenu Pazuhinım, Poslannım v Buharu, Belh i Yurgenç 1669", s. 58.
}

\section{History Studies}


istediğinden görüşmeleri uzatmaktaydı. Bu nedenle Boris Pazuhin'in bu ilk temaslarında öncelik esir meselesi olamamıştır. Ayrıca Abdülaziz Han kendisi üzerinde hegemonya kurmak isteyen Çar'ın özel hayatı, hobi ve uğraşları hakkında bilgi sahibi olmak istemekteydi. Bu nedenle Boris'in esir sorusunu geçiştirdikten sonra Çar'ın nasıl eğlendiğini sormuştur. Bu konu hakkında yeterli bilgi sahibi olmayan elçi, Çar'ın istediği her şeyi yapabileceğini ifade etmiştir. Ancak Abdülaziz Han'ın asıl bilmek istediği o dönem itibariyle oldukça değerli yırtıcı bir kuş türü olan Akdoğanların ${ }^{60}$ Rus Çarlığında olup olmadığıydı. Zira Han'ın, Akdoğan ve diğer kuşlar ile vakit geçirmeyi sevdiği bilinmekteydi. Pazuhin, Çar'ın Akdoğanları olduğunu söylemiştir. Ancak bu konu hakkında yeterli bilgi sahibi olmadığı nakazlardan anlaşılmaktadır. Zira Rus Çarlığındaki Akdoğan ve diğer kuşlar hakkında detaylı bilgi veren Türkistan ve Buhara araştırmalarında önemli eserler veren Burton, Çar'ın yüz binlerce kuşu olduğunu ve onların bakımı için ilgilenen bir birim kurduğunu ifade etmektedir. ${ }^{61}$ Elçiyle aralarında geçen bu konuşmanın ardından Abdülaziz Han iki Akdoğan getirterek iki omzuna koymuştur. Kuşların oldukça iyi eğitildiğini gözlemleyen Boris, Han'ın onları çok rahat kontrol ettiğini söylemektedir. Aslında Abdülaziz Han omuzlarına yerleştirdiği Akdoğanlar ile Rus elçisine sahip olduğu gücü de göstermek istemiştir. Bu görüşmedeki diğer bir ilginç durum ise, Abdülaziz Han'ın diplomasi yeteneğinin üst düzeyde olduğunu göstermektedir. Han, Boris Pazuihin'den kendisine mümkün olduğunca fazla Akdoğan'1 hediye olarak göndermesini talep etmiştir. Rus Çarlığının, Buhara Hanlığı üzerinden gücünü tesir ettirmek isterken, Han MoğolTürk hakimiyeti döneminden gelen haraç ödemelerini devamı niteliğinde bir istekte bulunmaktayd1. ${ }^{62}$

Boris Pazuhin ve maiyetinin Buhara'da bulunduğu süreçteki en renkli anlar kuşkusuz Rus elçilik heyeti onuruna verilen resmi ziyafetlerdi. Bu yemeklerde Han'ın verdiği davet elçi raporlarında tüm ayrıntıları ile tasvir edilmiştir. Boris Pazuhin'in onur konuğu olarak kabul edildiği bu yemekler aslında Han'ın tüm cömertliği ve zenginliği resmedilmiştir. Nitekim bir önceki Rus elçisi Hohlov'un Hive'de ağırlandığı yemek düşünüldüğünde, misafirlere sunulan yemek çeşidi farklı zaman dilimlerinde, karşıllıklı ilişkilerin derecesiyle mütenasip olup onların temsil ettiği ülkeye verilen saygı derecesini de göstermekteydi. ${ }^{63}$ Masalar yaldızlı sırmalı kumaş ile kaplanmıştı. Menü çok zengindi; et çeşitleri, meyveler, tatlılar oldukça düzgün bir biçimde masaya yerleştirilmişti. Boris Pazuihin masadaki tabakların altın renginde ve çok kaliteli olduğunu belirtmiştir. Masada yabancı bir elçi bulunmadığını ifade eden Boris Pazuhin, yemekte Han'ı devlet ricalini oldukça ayrıntılı betimlemiştir. Boris Pazuhin'in aktardığı üzere;

Han masanın en başında oturmakta; kılıcl, yayl, kalkanı ise hemen yanında durmaktaydı.

Hanın să̆ tarafinda din adamları oturmakta, arkasinda ise on iki asker teçhizatları olan asa ve kilıçları ile belli aralıklarda yer değiş̧tirerek beklemekteydi. Yemekte, Han'ın üst rütbeli komutanları ve emirleri aynı mertebede oturmaktaydl. Bunun dışında iki yüz kişilik bir heyet de Han'ın önünde konumlanmıştı. Bu heyetin hemen arkasındaki yükseltinin her

\footnotetext{
${ }^{60}$ Pazuhinlerden önce Buhara’ya giden İvan Hohlov Buhara Hanı, İmamkulu’na Akdoğan hediye ettiği bilinmektedir. Bkz., Sbornik Knyazya Hilkova, s. 396-397.

${ }^{61}$ Burton, Audrey, The Bukharans: Dynastic, Diplomatic and Commercial History, 1550-1702, s. 147,148-165.

62 "Nakaz Borisu i Semenu Pazuhinım, Poslannım v Buharu, Belh i Yurgenç 1669", s. 51-52.

63 İvan Hohlov'un Hive ziyaretinde kendileri sadece ekmek, yarım karpuz, kuru üzüm ikram edilmesi, iaşe olarak bir koyun, az miktarda odun, ekmek, kavun ve karpuzun verilmesi memnuniyetsizliğin ne seviyede olduğunun da göstergesidir. Bkz., Sbornik Knyazya Hilkova, s. 397-398.
} 
iki yanında dokuz asker arkebüzle ${ }^{64}$ duruyordu. Yemek boyunca dokuz müzisyen şarkı söyleyip milli oyunlar sergilemekteydi. Masadaki yemekleri mehter adl bir görevli getirmekteydi. Yemekler öncelikle Han'a sunulmaktaydl. Masada 17 tabak sebze, her kapta 4 farklı yemek olmak üzere 17 kâse yemek vardı. Han'in önündeki tabaklar altınd. Ayrica bu ziyafet esnasinda Kuran'dan ayetler de okunmuştu.

Yemek sırasında ilginç sahneler de sergileniyordu. Bir vahşi hayvan elçilik heyetinin önüne getirilmişti. Bu hayvanın yukarıya doğru yükselen siyah boynuzu ${ }^{65}$ olduğunu belirten Boris, Han'a bu hayvanı daha önce görmediğini söylemiştir. Han başka yemeklerde de aslan, kaplan, fil, geyik ve çeşitli kuşları konuklarına sergilemişti. Abdülaziz Han, ülkesinin zenginliğini tüm yönlerini Rus elçisine göstermeyi istiyordu. Bu durum aynı zamanda devletlerin sahip olduğu ülkelerin iklimlerin, zenginliğin sınırları hakkında bilgi veren bir semboldür. Ancak Boris akıllı bir diplomattı. Çar'ın kendisine zor durumlarda kullanması için verdiği mors dişlerini Han'a göstererek bu psikolojik savaştan galip çıkmak istiyordu. Nitekim sınırlarının genişliği ve kudreti ile övünen Rus Çarlığının da Han'ın sahip olmadığı bir hayvana sahip olması önemli bir husustu. Pazuhin bu hareketi ile başarılı oldu zira nadir bulunan mors dişi değerli bir emtia olarak biliniyordu. Hatta Rusların bir dönem Kırım Hanlığına haraç adı altında mors dişi verdiği bilinmekteydi. ${ }^{66}$ Abdülaziz Han'ın da bu dişler oldukça ilgisini çekmiş, onların nasıl elde edildiğini ülkesinde ne kadar olduğunu elçiye sormuştu. Pazuhin mors dişlerini Arhangelsk yakınlarından elde ettiklerini açıklamıştır. Yemek faslının sonuna yaklaşıldığında Han misafirlerine kımız ikram etmiştir. ${ }^{67}$

Boris Pazuhin ile Abdülaziz Han arasında çözülemeyen en önemli sorunun Rus esirler konusu olduğu açıktı. Rus elçilik heyeti iki defa Han'ın sofrasında bulunmuş ancak yine bu konuda bir çözüm üretilememiştir. Bu neden Boris Abdülaziz Han üzerinde nüfuz sahibi olacak yüksek rütbeli memur ve soylular ile görüşmeler yapmıştır. Bu memurlara değerli hediyeler veren Boris Pazuhin, Rus esirlerinin serbest bırakılması için onlardan yardım istemiştir. Ancak bu memurlar esirlerin Müslüman olduğu için Han'ın onları serbest bırakmasının mümkün olmadığını söylemişlerdir. Bunun üzerine Boris Pazuhin esirlerin seçim hakkı olmadığından Müslümanlığı tercih etmek zorunda kaldıklarını ifade etmiştir. ${ }^{68}$

Boris Pazuhin ve maiyeti bir yıldan fazla kaldıkları Buhara'da defalarca Han'ın huzuruna kabul edilmiş, ziyafetlere katılmış ve temaslarda bulunmuşlardır. Ancak Rus esirleri konusunda Abdülaziz Han ile uzlaşamamışlardır. Ancak 20 Eylül'de elçilik heyeti artık dönüş yolcuğu için hazırlık yaptığında Han, dokuz esiri bedelsiz bir biçimde serbest bırakmıştır. ${ }^{69}$ Han, esirlerin serbest bırakılmasının Rus Çarlığının gücü ile alakalı olmadığını bu lütfun dostluk nişanesi olarak gerçekleştiğini ifade etmiştir. Eğer Çar daha fazla esirin serbest kalmasını istiyorsa 1688'de Moskova'ya giden ve alıkonulan Buhara elçisi Molla Faruki'yi huzuruna kabul

\footnotetext{
${ }^{64}$ XV-XVII. Asırda namludan doldurulan kısa menzilli bir tüfek türü.

${ }^{65}$ Boris Pazuhin'in tarif ettiği hayvanın Gergedan olma ihtimali yüksektir.

${ }^{66}$ Akdes Nimet Kurat, Rusya Tarihi., Türk Tarih Kurumu, Ankara 1999, s. 157, Ayrıca bu konu hakkında son zamanlarda yapılmış olan ehemmiyetli çalışma için bkz., Serkan Acar, "Moskof Çarlarının Kırım Hanlarına Ödediği Bir Haraç Türü: Tiş-Tiyiş (Mors Dişi)", Karam, C. XV/60, 2018, s. 34-45.

67 "Nakaz Borisu i Semenu Pazuhinım, Poslannım v Buharu, Belh i Yurgenç 1669", s. 51-53.

68 "Nakaz Borisu i Semenu Pazuhinım, Poslannım v Buharu, Belh i Yurgenç 1669", s. 54.

69 "Nakaz Borisu i Semenu Pazuhinım, Poslannım v Buharu, Belh i Yurgenç 1669”, s. 54.
} 
etmeliydi. Eğer bu gerçekleşirse Rus elçiler fidye karşılı̆̆ında serbest kalabilirdi. Ayrıca Moskova'ya gönderdiği bir diğer elçi Nazar-Bey ${ }^{70}$ Kalmukların yerleşim bölgesindeki bir ziyafette soyulmuştu. Bu nedenle Abdülaziz Han bir elçisinin Pazuhinler ile Moskova'ya gitmesini istiyordu. ${ }^{71}$ Ancak Han'ın bu isteği gerçekleşmemişti.

Boris Pazuhin, Buhara memurlarından pervaneçi ${ }^{72}$ aracılığı ile Çarın mektubunu Abdülaziz Hana iletmiştir. Kendisine verilen talimatnameye göre karşıllğında bir mektubun da Han tarafından Çar'a sunulması gerekiyordu. Bu nedenle Han mektubunu yazana dek Buhara'da kalmaya devam etmiştir. Bir taraftan da Rus esirlerinin özgürlüğe kavuşması noktasında başarı elde edemeyen Boris, dönüş için hazırlıklara başlamıştı. Nakazda belirtildiği üzere dönüş yolu masraflarını Buhara Han'ı karşılamalıydı. Ancak Abdülaziz Han Buhara'dayken Rus elçiliğin tüm ihtiyaçlarını karşılamasına rağmen dönüş için onlara bir iaşe veremeyeceğini ifade etmiştir. Buna karşın Boris Pazuihin ve heyeti oldukça kıymetli hediyeler takdim edilmiştir. Buna göre Pazuhin kardeşlerin her birine ipek kumaştan kaftan, altın bir hançer, zerdeçal ve birer at verilmiştir. Elçilik heyetinde bulunan diğerleri için kuşak ve kaftan hediye edilmiştir. Böylece elçilik heyeti 7 Kasım 1671'de Buhara'dan ayrılmıştır. ${ }^{73}$

\section{Dönüş Yolu}

Hive ve Buhara'daki misyonunu tamamlayan Pazuhin kardeşler dönüş yolu için İran güzergâhı olan Çarçuy, Merv, Meşhed, Bakü ve Şemahi istikametinde yol alarak önce Astarhan'a daha sonra Moskova'ya ulaşmışlardır. Pazuhinlerin bu yolu tercih etmelerinin öncelikli sebebi Hive Hanı Anuşa'nın onları tutuklatacağı hakkında istihbarat almış olmalarıydı. Zira Boris ve Anuşa Han esirlerin iadesi konusunda anlaşamamışlardı. Bu nedenle Han, Türkmenleri Rus elçilik heyetine saldırması için teşvik edebilirdi. Ayrıca Abdülaziz Han'ın Rus elçilik heyetinin Astarhan'a ulaşmaları için bu güzergâhta bulunan Türkmen tehdidine karşılık güvenli bir biçimde seyahat etmeleri için Merv ve diğer bölge valilere mektup yazması bu yolu tercih etmelerinde etkili olmuştur. ${ }^{74}$

Pazuhin kardeşler 1672 yılının Mart ayında Merv'e ulaştıklarında seyahat izni almak için 3 ay beklemek zorunda kalmışlar ve nihayet Meşhed'e ulaşmışlardı. Astarhan istikametinde ilerleyen elçilik heyeti Talis'teki görevliler tarafından durdurulmuş ve gümrük ödemeleri gerektiği bildirilmiştir. Rus elçilik heyetinin bu talebi kabul etmemesi üzerine tercüman Nikita Medvedev ve Samaralı muhafız Maksim Yakovlev'i öldürmek istemişlerdir. Daha sonra elçiliğin yirmi dört ruble değerindeki malını gasp etmişlerdir. Rus elçilerinin soyulduğunu duyan bölge yöneticisi Mudzher Khan? (Medzher-Khan) elçiliğin gasp edilen mallarının neredeyse iki katı değerinde olan yirmi dört atı hediye olarak onlara vermiştir. Yoluna devam

\footnotetext{
${ }^{70}$ Aslında bu elçi Yayık bölgesinde bir kez daha soyulmuştur. Burton, The Bukharans: Dynastic, Diplomatic and Commercial History, 1550-1702, s. 290-291.

71 "Nakaz Borisu i Semenu Pazuhinım, Poslannım v Buharu, Belh i Yurgenç 1669”, s. 55-56.

72 Buhara devlet teşkilatında Han'ın fermanları ve diğer resmi yazışmaların sorumlu görevli. Bkz., Burton, The Bukharans: Dynastic, Diplomatic and Commercial History, 1550-1702, s. XV; Nurettin Hatunoğlu, "Buhara Hanlığ 1 , s.491.

${ }^{73}$ Pazuhinlerin raporunda bu hediyelerin değerleri de yazılmıștır. Elçiliğin temsilcisi konumunda olan Boris'e 25 ruble, Semen'e 12 ruble ve diğer üyelere 3 buçuk ruble değerinde eşyalar verilmişti. "Nakaz Borisu i Semenu Pazuhinım, Poslannım v Buharu, Belh i Yurgenç 1669", s. 55, 71.

74 "Nakaz Borisu i Semenu Pazuhinım, Poslannım v Buharu, Belh i Yurgenç 1669”, s. 68-70
} 
eden Pazuhinler Bakü'den Hazar Denizi kıyısında bulunan Nizovoy Limanı'na doğru yola çıkmıştır. Ancak buraya ulaştıklarında kendilerini Astarhan'a götürecek bir geminin olmadığını fark etmişlerdir. Nitekim elçiliğin kiralayabileceği gemi bir ay sonra limana geldiğinde ise Kasım ayı olmuştu. Hava muhalefeti dolayısı ile elçilik baharın gelmesini beklemek zorunda kaldı. Pazuhin kardeşlerinin dönüş tarihinin planlananın ötesinde olması paralarının tükenmesine neden olduğundan Şamah’ta bulunan Polonya elçisi Bogdan Pers’ten iki yüz elli ruble borç almışlardır. Ancak elçilik Dağıstan bölgesi yönetimi altındaki topraklarda tekrar saldırıya uğramıştır. ${ }^{75}$

1673 Haziranı'nda Rus elçilik heyeti Astarhan'a gitmek için hazırlıklara başlamıştır. Boris Pazuhin kiraladıkları gemiyi on sekiz gün limanda bekleterek Astarhan'a çok sayıda tüccar ve emtia götürmek istemiştir. Nihayetinde Rus elçilik heyeti 29 Haziran 1673'te üç yıllık seyahatlerini tamamlayarak Astarhan'a ulaşmışlardır ${ }^{76}$.

\section{Hedefler, Gerçekler, Pazuhinlerin Misyonu}

Pazuhin kardeşlere tevdi edilen görevlerin yerine getirilmesi bu misyonun başarıya ulaşıp ulaşmadığının da kanıtıdır. Türkistan bölgesi hakkında bilgi toplamak elçilik heyeti için en önemli hususlardan biriydi. Bir nevi casusluk sayılabilecek bu talebin karşılanması ancak Han ve yöneticilerin Rus elçilerine vereceği bilgiler kadar olacaktı. Bu görüşmelerde Rus elçilik heyeti de karşı tarafa önemli malumatlar vermiştir. Pazuhinler, Rus Çarlığının Kırım Hanlığı, Osmanlı Devleti ve İran ile ilişkileri hakkında bilgi verip karşılığında Buhara'da yüz elli bin, Hive'de otuz bin ve Belh'de yirmi bin kadar asker olduğunu öğrenmiştir. Bunlardan ziyade Türkistan Hanlıklarının Kazak ve Karakalpak halkından takviye birlikler de aldığı tespit edilmiştir. Bölge halklarının askeri teknolojisinin çağın gerisinde olmakla birlikte develerin üzerine yerleştirilen ve zenburek adı verilen toplara sahip oldukları öğrenilmiştir. ${ }^{77}$ Hatta Hive ve Belh'de topraklar çok verimsiz olduğundan atların beslenmesi güçlükle sağlanmaktaydı.

Pazuhinler bölgenin siyasi anatomisini de öğrenmeyi başarmıştı. Buna göre; Buhara Hanlı̆̆g'nın Osmanlı Devleti ile ilişkileri yoktu ${ }^{78}$. Belh ve Hive'nin Babürler ile ilişkilerinde dostluk havası hakimdi. Hive yönetiminin Safevi Devleti ile ilişkileri oldukça gergindi çünkü Hive Han'1 Anuşa (1663-1689) defalarca Şah'ın şehirlerine saldırmıştı. Şah'ın misilleme yapması an meselesiydi. Hive'nin Belh ile de ilişkileri kötüydü. Ürgenç'in kontrolü Hive Hanlığı'na bağlıydı. Buhara Han'ı Abdülaziz'in, Belh hâkimi kardeşi Sübhankulu ile arasındaki mücadelede Hive'nin Buhara yönetimini destekleyerek askeri faaliyette bulunması bu ilişkilerin kötüye gitmesine sebep olmuştu. Safevi Devleti, Ermenistan topraklarını kontrol etmekteydi. $^{79}$

Elçilik heyetinin görevlerinden biri de Hindistan'a uzanan ticaret yolları hususudur. Buhara ve Belh arasında ihtilaf olmasından dolayı Pazuhin ve ekibinin bölgeye giderek bilgi toplaması

\footnotetext{
75 “Nakaz Borisu i Semenu Pazuhinım, Poslannım v Buharu, Belh i Yurgenç 1669”, s. 71-73

76 "Nakaz Borisu i Semenu Pazuhinım, Poslannım v Buharu, Belh i Yurgenç 1669", s.74.

77 "Nakaz Borisu i Semenu Pazuhinım, Poslannım v Buharu, Belh i Yurgenç 1669”, s.61;

78 XVII. Yüzyılda Buhara Hanlığı ve Osmanlı Devleti arasındaki diplomatik yazışmalar göz önüne alındığında Boris Pazuhin'in yanlış bilgilendirildiği ortaya çıkmaktadır. Ayrıntılı bilgi için bkz., Belgelerle Osmanll-Türkistan İlişkileri $(X V I-X X)$, Başbakanlık Devlet Arşivleri Yayınları, Ankara 2004.

79 "Nakaz Borisu i Semenu Pazuhinım, Poslannım v Buharu, Belh i Yurgenç 1669”, s. 60-61.
} 
oldukça zordu. Bu nedenle iki casus tercüman Nikita Medvedev ve Semen İsmail, Belh'den hareketle Astarhan ile Hindistan Hanı Uranzep ${ }^{80}$ in bulunduğu Zhnabat şehrine kadar olan yolu öğrenmek için görevlendirildi. Medvedev ticaret yolları hakkında malumat toplamayı başarabilmişti. Buna göre; Astarhan'da bulunan Kerrigan iskelesinden Hive'ye ulaşmak üç hafta sürüyordu. Bu yolda vergi ödemek gerekiyordu. Hive'den Belh'e, seyahat etmek üç haftadan daha az sürüyordu. Bu istikametteki ilk Hint şehri olan Parvan'a gitmek dört haftaydı. Parvan'dan, Çarikar şehri iki gün, oradan Kaval'a gitmek ise bir gün sürüyordu. Kaval'dan Büyük Çarikar şehri iki gün, oradan Peşaver ise altı günlük mesafedeydi. Peşaver'den Atak nehrini aşmak iki gün, oradan Ratas'a ulaşmak ise beş günlük bir yolculukla gerçekleşebiliyordu. Ratas'tan, Dzhilim'e oradan Chinov nehrini geçene kadarki mesafe altı gündü. Buradan Küçük Gurjarat şehri iki gün oradan Lagur şehri ise iki haftalık uzaklıktaydı. Buradan Sultanpur şehri üç gün, Zhanabat'a ulaşmak için ise iki haftalık bir yolculuk gerekiyordu. Medvedev'in verdiği rapora göre Belh ve Zhanabat arası deve ile yaklaşık olarak dört buçuk ay sürmekle beraber iki şehir arasındaki güzergâh güvenliydi ve yol boyunca herhangi bir vergi alınmadığ 1 bilgisi edinilmiştir. Safevi Şahı ve Hindistan Han'1 arasındaki ilişkiler kötü olduğundan İran üzerinden Hindistan'a ulaşmak, oldukça tehlikeliydi Hindistan'a giden güzergâh hakkında önemli bilgiler veren tercüman Medvedev elçilik heyeti adına Hindistan ile Rus Çarlığı arasında ticari ilişkiler geliştirmek için mutabakat da yapabilmiştir. ${ }^{81}$

Boris'e verilen talimatnamede Hindistan'a giden ticaret yollarının mutlaka öğrenilmesi isteniyordu. Medvedev'in çizdiği en makul Hindistan rotasında Belh önemli bir yerdi. Ancak Buhara Han'ı ile Belh Hanı Sübhankulu'nun arasındaki hakimiyet mücadelesi bu güzergahta yolculuk yapmayı zorlaştırıyordu. Bu nedenle Boris tercümanı Medvedev'i gizlice Belh'e göndermiştir. 1671'in Mayıs ayında Belh'e varan Medvedev, Han'ın Divanbeyi ile görüşebilmiş ona Çar'ın mektubu vermiştir. Bunun üzerine Divanbeyi de Rus Çarlığına iletilmek üzere, Medvedev'e bir mektup teslim etmiştir. Bu mektuba göre Belh hâkimi Subhankulu, Rus Çarlığı ile dostane ilişkilere vurgu yaparak elçi teatisi yapılmasını istiyordu. Belh'de kısa süre kalan tercüman Medvedev, Han'in hizmetinde 100 kadar Rus esirin olduğunu ve ticari açıdan bölgenin oldukça güven arz ettiğini belirtmiştir. ${ }^{82}$

Çar'ın talimatlarından biri de İran, Osmanlı ve oradan Alman topraklarına giden Buhara ipeğinin Moskovalı tüccarlara ulaştırılmasıydı. ${ }^{83}$ Pazuhinlerin elçilik raporuna göre Hive'de yıllık 1000 torbadan daha fazla ipek üretilmekteydi. İpeğin birim fiyatı 34 rubleydi. Hive'deki ipeğin büyük kısmı Buhara'ya satılmaktaydı. Bu nedenle Rus Çarlığı ile ipek ticareti yapılmamaktaydı. Ancak, kaliteli Rus kürkleri ve derileri ile ipek takası yapılabilirdi. Astarhan valisi ricalinden İvan Savalev, ipek ticareti için Hiveli tüccarları ikna etmek için Boris'in elçilik heyeti içerisinde yer almıştır. Önemli temaslarda bulunan Savalev, ertesi sene için ipek ticareti hususunda Hive Hanı Anuşa ile anlaşma yapmayı başarmıştır. ${ }^{84}$

\footnotetext{
${ }^{80}$ Awrangzib olarak da bilinmekteydi.

81 "Nakaz Borisu i Semenu Pazuhinım, Poslannım v Buharu, Belh i Yurgenç 1669", s. 62-63. Safevi ve Babür ilişkileri hakkında bkz., Eralp Erdoğan, "Şah I. Tahmasb (1524-1576) Döneminde İran-Hindistan İlişkileri” Türk Tarihine Dair Yazllar III, Ankara 2018, s. 65-74.

82 "Nakaz Borisu i Semenu Pazuhinım, Poslannım v Buharu, Belh i Yurgenç 1669”, s 65

83 "Nakaz Borisu i Semenu Pazuhinım, Poslannım v Buharu, Belh i Yurgenç 1669”, s. 17.

84 “Nakaz Borisu i Semenu Pazuhinım, Poslannım v Buharu, Belh i Yurgenç 1669” s. 68.
} 
Pazuhin kardeşlerin önemli görevlerinden biri de Türkistan hanlıkları ile daha önceden de defalarca devletlerarası sorun teşkil eden Rus esirleri meselesiydi. Rusların doğu istikametinde hızlı genişlemesi ve imparatorluğun sınırlarının kontrol edilemez büyüklüğe ulaşması haliyle merkezi otoritenin hissedilmediği bölgelerde yönetim zafiyetlerinin yaşanmasına neden olmuştur. Bilhassa Türk yerleşim birimlerine yakın Rus şehirlerinden oldukça fazla esir alınmış ve bunlar hanlıkların elinde hem önemli bir ekonomik araç hem de güçlenen Çarlığa karşı siyasi bir argüman olmuştur. ${ }^{85} \mathrm{Bu}$ esirlerin bazıları asker olduğu için ateşli silah yapımından anlamaktaydı. Pazuhin kardeşlerin bölgede bulunan esirleri kurtarması Rus imajını ve otoritesinin Türkistan coğrafyasında itibar kazanması için önem teşkil etmekteydi. Bu nedenle elçilik faaliyeti süresince mutabakatları yürüten Boris Pazuhin'in en çok üzerinde durduğu konu Rus esirleri sorunuydu. Buhara'da dokuzu Abdülaziz Han tarafından olmak üzere $31^{86}$ esirin serbest bırakılmasını sağlayan Boris, bu esirlerin özgürlüğü için 685 ruble ödemiştir. Hive'deki esirler ise Anuşa Han ile devam eden müzakerelerde fidye konusunda uzlaşılamamasından dolayı serbest bırakılmamıştır. Hem Hive hem de Buhara yönetimi Rus esirlerin kendileri tarafindan ele geçirilmediğini Kalmuk ve Başkurtların onları esir edip sattığını ileri sürmüştür. ${ }^{87}$ Rus esirlerin serbest kalma sürecinde esas müzakere tutsakların dini inancı üzerinden yürümüştür. Boris Pazuhin, bütün Hıristiyan kölelerin serbest bırakılması talebinde bulunmuş, buna karşılık Abdülaziz Han onların artık Müslüman olduğunu söylemiştir. Bunun üzerine Boris kendi iradeleri dışında onların Müslüman edildiğini ileri sürmüştür. Hatta esirler ile gizli bir görüşme yapan Boris bu bilgiyi teyit etmiştir. ${ }^{88}$

Boris Pazuhin'in önemli ve hatta en ilginç görevlerinden biri de Aziz Simon'un kemiklerinin akıbeti hakkında bilgi toplayarak Moskova'ya getirmekti. Pazuhin kardeşlere bu görevi gerçekleştirmek için oldukça az bilgi verilmiştir. Buna göre; Aziz Simon'un 700 yıl önce yaşadığı, İran topraklarında Pir-Mirizat veya Pir Magudat köyünde bir kilisenin kuzey kapısı tarafında gömülü olduğu ve ona inanmayan Müslümanları kör ettiği bilgisi nakazda yer almıştır. ${ }^{89}$ Böyle bir kişiliğin kemiklerinin Müslüman Safevi topraklarından Ortodoks Rus Çarlığına iade edilmesi şüphesiz din sembolizmine verilecek önemli bir örnektir. Nitekim bu

${ }^{85}$ Pazuihn'e göre Buhara'da 150, Hive'de 50, Belh'de ise 100 esir vardı, Bnz., "Nakaz Borisu i Semenu Pazuhinım, Poslannım v Buharu, Belh i Yurgenç 1669" s. 59.

${ }^{86}$ Fidye karşılığında serbest kalan 22 esirden 15'i askerdi. Bu durum Rus esirlerin kurtarılmasında asker kökenlilerin öncelik taşıdığını göstermektedir. Bu esirlerin her biri ayrı pazarlıklar neticesinde özgürlüğünü kazanmıştır. Buna göre, Sibirya'da görevli hafif süvari asker Grigori Rastovski 25 ruble, Fedor Aristov, 29 ruble, Boyar Lavrentey Shatilov'un oğlu Kozlovets, 33 ruble, Yakovlev Solovtsov komutasındaki Moskova silahşörü Luchek 37 ruble, 16 altın ve iki denga, Nikiforov Kolobov'un komutasındaki Moskova silahşörü Grishek, 41 ruble, sekiz altın ve iki denga, Moskova silahşörü, Aleska Samarkonki, 29 ruble, sekiz altın iki denga, Moskova silahşörü, Grishek Kolashnik, 37 ruble, 16 altın, 4 denga, asker, Ivasko Guliaev 18 ruble, Jakushek Stepanov'un çavuşu Lomovets, 23 ruble, Kazak toprakların esir alınan Ivashek, 40 ruble, Kazan silahşörü Fetek Cernoy, 42 ruble, 16 altın, ve 4 denga, Samara Silahşörü Ivshek Koptev, 43 ruble, yine Samara silahşörü, Senej Mikhailov, 45 ruble, silahşör Kafonek Moiseev 45 ruble, silahşör Ivasko Mikhail, 30 ruble, Maksimko Mikiforv, 44 ruble, 13 altın ve iki denga, Astarhan silahşörü, İvasko Miasnikov, 35 ruble, Arbuz köylüsü Kanuskin 9 ruble, Astarhanlı silahşör, 5 ruble, Arbuz köyü kilisesindeh Matrenek'in eşi, 46 ruble, Kazan'da bulunan kilisesinden Maver eşi, 5 ruble, sekiz altın, iki denga, Silahşör Koptev, iki ruble. Bkz., "Nakaz Borisu i Semenu Pazuhinım, Poslannım v Buharu, Belh i Yurgenç 1669", s. $154-156$.

87 "Nakaz Borisu i Semenu Pazuhinım, Poslannım v Buharu, Belh i Yurgenç 1669", s. 58

${ }^{88}$ Ron Sela, "Seventeenth-Century Russian Diplomatic Mission to Central Asia", s. 82.

${ }^{89}$ Aslında Simon'un aziz olup olmadığı belli değildi. Ayrıca Rusların Hristiyanlığı kabul ettiği Vladimir (988) dönemi düşünüldüğünde Ruslara Hristiyanlığı vaaz eden ilk din adamlarından biri olabilirdi. Bkz. "Nakaz Borisu i Semenu Pazuhinım, Poslannım v Buharu, Belh i Yurgenç 1669”, s. 16.

\section{History Studies}


mühim görev Rus Çarlığının, Ortodoks Hıristiyanlığı üzerinde din ve mezhep merkezli bir hâkimiyet kurma girişimini temsil ediyordu. Eğer Ortodoks Hıristiyanlığı temsil eden kutsal emanetler Çarlık topraklarına getirilirse şüphesiz Çarlık idaresinin saygınlığının artacağı düşünülmekteydi. Böylece Çarlık hem içeride kendi tebaası olan Ortodoksların hem de otoritesi dışındaki Müslümanların gözünde Rus imajını güçlendirecekti. Zira Müslümanları kör etme gücüne sahip Hıristiyan bir Aziz’in Müslümanlar üzerindeki gücü tartışmaya mahal vermeyecek prestij sunmaktaydı. Bu nedenle Aziz Simon'un kemiklerinin bulunması görevi Çarlık yönetimi için önem arz etmekteydi. Bunun bilincinde olan Boris, bu zor görev için Hive ve Buhara seyahatinin dönüş yolunda Aziz Simon'un mezarının olduğu düşünülen Şamah'a gitti. Ancak bölgede kimse Aziz Simon'un mezarı hakkında bilgi sahibi değildi. Boris'e verilen bilgiye göre Şamah yakınlarında bulunan bir klisede olduğu bilgisi ile hareket eden elçi, nakazdaki tariflerin aksine Simon'un kemiklerinin bir cami bahçesinde olduğu tespit etmiştir. Burada camii cemaati ve hocası ile görüşen Pazuhin, onlardan mezarın Müslüman bir kişiliğe ait olduğunu öğrenmiştir. Hatta cami hocası mezarın 700 yıl önce Türk topraklarından getirildiğini ve burada yatan zatın Pir-Magamet/Pir-Miruz olduğunu belirtmiştir. ${ }^{90}$ Daha önce de çok sayıda Rus vatandaşının bölgeye gelerek Aziz Simon'u sorduklarını belirten cami hocası, burada yatan kişinin Hıristiyan olmadığını tekrarlamıştır. Görüleceği üzere bu durum din sembolizminin ne kadar değişken olduğunu göstermekle beraber Rus Çarlığının çabalarının tümüyle boşa çıkmasına sebep olmuştur. ${ }^{91}$

\section{Sonuç}

XVII. asrın başlarında kendi iç işlerinde büyük bir kaosla karşı karşıya kalan Çarlık yönetimi aynı yüzyılın ortalarında bu mücadeleden galip gelerek Türkistan içlerine doğru genişleme politikası gütmüştür. Bu politikanın sac ayaklarından birisi bölgeyi tanımak ve buna göre ilerleme stratejisini kurgulamak olmuştur. 1699'da Çar Aleksey Mihaloviç tarafindan Hive ve Buhara'ya gönderilen Pazuhin kardeşler bu misyonu üstlenmişlerdir. Türkistan'da geçirdikleri 3 yıllık süreçte Pazuhinler, önemli kazanımlar elde etmişlerdir. Türkistan Hanlıkları ve Hindistan ticaret yolları hakkında bilgi toplamaları, Rus esirlerinin bir kısmının özgür kalmasını sağlamaları ve Rus Çarlığının Hanlıklar nezdinden ritüeller üzerinden diplomatik üstünlük sağlamaya çabaları ilgili dönem açısından ziyaretin kısmen başarılı olduğu yönünde bir izlenim bırakmaktadır. Nitekim Buhara ve Hive Hanlıkları üzerinde güç tesis etmek isteyen Çarlık, hanlıkların esirler konusundaki akıllıca stratejileri neticesinde bu girişimden sonuç alamamıştır. Ayrıca Aziz Simon’un naaşını beraberinde getirememesi de Pazuhinlerin başarısına gölge düşüren baka bir etken olmuştur.

Pazuhin kardeşlerin seyahati neticesinde Türkistan hakkında tuttukları notlar göz önüne alındığında daha önceki elçilik misyonlarına nazaran daha renkli ve betimleyici ifadelere rastlanması, resmi görüşmelerdeki protokolleri resmetmeleri iki hanlığa dair bilgileri derinleştirmektedir. Ancak bu raporlar, günlük hayat, ekonomi ve din hakkında oldukça sessizdir. Boris Pazuhin, daha önceki elçiliklerin aksine kendi nevi şahsına münhasır bir anlatı

\footnotetext{
${ }^{90}$ Hakimiyet alanlarının değişimi üzerinden dini mekanların evrilmesi ve hâkim unsurun kutsal mekanına dönüşmesi sürecinin örneklendiği çalışma için bkz., Sadullah Gülten, "Hızır-İlyas Zaviyeleri, Aya Yorgi ve Bektaşiler", Türk Kültürü ve Hacı Bektaş Veli Araştırma Dergisi, S. 83, Güz 2017, s.81-100.

91 "Nakaz Borisu i Semenu Pazuhinım, Poslannım v Buharu, Belh i Yurgenç 1669”, s. 73.
} 
sunsa da çağdaşlarından olan Avrupalı seyyahların anlatılarındaki coğrafi kavramları görmemiz mümkün değildir. Zira Rus Çarlığında bu türden geniş anlatımlar daha çok XVIII. asırda başlamıştır. Bu elçilik heyetinin en önemli kazanımı şüphesiz 1677 yılında Rus elçilerin Hindistan'a coğrafyasında ticari münasebetlere başlamasıdır.

\section{Kaynakça}

ACAR, Serkan "Moskof Çarlarının Kırım Hanlarına Ödediği Bir Haraç Türü: Tiş-Tiyiş (Mors Dişi)", Karam, C. XV/60, 2018, s. 34-45.

ANDERSON, M. S. The Rise of Modern Diplomacy, 1450-1919. New York 1993.

BURTON Audrey, The Bukharans: Dynastic, Diplomatic and Commercial History, 1550-1702, Richmond: Curzon Press, 1997.

BARTHOLD, V.V. Rusya ve Avrupa'da Oryantalizm (Çeviren: Kaya Bayraktar, Ayşe Mera), İstanbul 2004: Küre Yayınları.

BOHLEN, Avis "Changes in Russian Diplomacy under Peter the Great," Cahiers du monde Russe et Soviétique, Vol. 7, No. 3 (1966), s. 341-358.

CRUMMEY, Robert Aristocrats and Servitors: The Boyar Elite in Russia, 1613-1689. Princeton, New Jersey: Princeton University Press, 1983.

ERDOĞAN, Eralp "Şah I. Tahmasb (1524-1576) Döneminde İran-Hindistan İlişkileri” Türk Tarihine Dair Yazllar III, Ankara 2018, s. 65-74.

HOSKING Geoffrey, Rusya ve Ruslar Erken Dönemden 21. Yüzyıla, İletişim Yay., Çev. Kezban Acar, İstanbul 2011.

GÜLTEN, Sadullah "Hızır-İlyas Zaviyeleri, Aya Yorgi ve Bektaşiler", Türk Kültürü ve Hacı Bektaş Veli Araştırma Dergisi, S. 83, Güz 2017, s.81-100.

JENKINSON A. Early Voyages and Travels to Russia and Persia by Antony Jenkinson and Other Englishmen with Some Account of the First Intercourse of the English with Russia and Central Asia by way of the Caspian Sea, Vol. I., Edited by: E. Delmar Morgan and C.H. Coote, Printed for the Hakluyt Society, London.

JOHNSON, Jennifer, The Pazukhin Embassy: A Look at Political Portrayal of Power between Seventeent-Centuy Russia and the Uzbek Khanates, İndiana University, May1s 2010.

JUKOVSKIY, S.V., Snoşeniya Rossii s Buharoii Hivoy za Poslednee Trehsotletıe, Petrograd. 1915.

KALAN, Ekrem, Cungar Hanlığının Siyasi Tarihi, TTK, Ankara 2008.

KARAMZIN, Nikolay Mihayloviç İstoriya Gosudarstva Rossiyskogo, I, Moskova 2002.

KHODARSKOVSKY, Michael, Not By Word Alone: Missinary Policies And Reliğions Conversion in Russia, 1550-1780. Chicago 1997.

KOBRIN, V. B. “Stanovlcnie Pomesnoi Sistemu” Istırocheskie Zapiski 105, 1980, s. 150-195.

\section{History Studies}


KOÇ, Dinçer “XVI.-XIX. Yüzyıllarda Buhara Hanlığı'na Gelen Rus Diplomat ve Askerleri” TDA, C. 115, S. 227, Mart-Nisan 2017, s. 61-90.

KOLESNIKOV, Aleksandr, MATVEYEVA, Mariya, Rus Seyyahların Gözüyle Orta Asya, Çeviri Bilim Yay., İstanbul 2019.

KURAT, Akdes Nimet, Rusya Tarihi, TTK, Ankara 1999.

Sbornik Knyazya Hilkova, (1879) "Stateynıy Spisok Posolstva v Buhariyu Dvoryanina İvana Hohlova", S. Petersburg 1879, s. 388-439.

SELA Ron, "Seventeenth-Century Russian Diplomatic Mission to Central Asia", (edited by Nile Green), Writing Travel in Central Asian History, Bloomington and Indianapolis: Indiana University Press, 2013, ss. 69-88.

Sibornik Knyazya Hilkova, "Stateynıy Spisok Posolstva v Buhariyu Dvoryanina İvana Hohlava”, S Petersburg 1879, s. 388-439.

OŞANINA, E. H. "Hozyaystvo Pomeşikov Pazuhinıh v XVII-XVIII Vekah", Voprosu İstori, S.7, 1956.

ÖZKAN, Murat, "Bekoviç Gibi Kaybetmek: Aleksandr Bekoviç Çerkasskiy'in 1717 Hive Seferi”, MUTAD, C. V. s. 93-111.56, S. 7., s. 84-92.

TEPLOVA, V., Russkie Predstavitelli v Tsargrade 1496-1891, İstoriçeskiy Oçerk , S. Petersburg 1891.

TRUVOROVA, A. N. "Nakaz Borisu i Semenu Pazuhinım, Poslannım v Buharu, Belh i Yurgenç 1669" Ruskaya İstoriçeskaya Biblioteka, Arheografiçeskoy Kommissii, ss. $1 \mathrm{~S}$. Petersburg 1894, s. 1-81.

ÜKTEN, Selim Serkan “16-18. Asırlarda Buhara Hanlı̆̆ı'na Gelen Batılı Seyyahlar ve Seyahatnameleri”, Eskişehir Osmangazi Üniversitesi Sosyal Bilimler Dergisi, S. 18(2), Aralık 2017, s.137-164.

ÜKTEN, Serkan Buhara Hanlı̆̆ı'nın Askeri Teşkilatı (1500-1868), Ankara Üniversitesi Sosyal Bilimler Enstitüsü, Doktora Tezi, Ankara 2015.

VERNADSKY, George Rusya Tarihi, Çev., Doğukan Mızrak, Egemen Ç. Mızrak, Selenge Yay., İstanbul 2011.

VESELOVSKIY, N.İ. İvan Daniloviç Hohlov, S. Petersburg, 1891. 